\title{
Science Teachers' Perspectives on Science-Technology-Society (STS) in Science Education
}

\author{
Nasser Mansour* \\ Graduate School of Education, University of Exeter, St. Luke's Campus, Heavitree Road, Exeter, EX1 2LU, UK.
}

Received 05 May 2010 - Accepted 09 October 2010

\begin{abstract}
Research supports the idea that teachers are crucial change agents in educational reform and that teachers' beliefs are precursors to change. This study investigates Egyptian science teachers' beliefs about teaching and learning science through Science Technology and Society STS education. Data were collected using a questionnaire. The findings of this study suggest that the Egyptian science teachers hold mixed beliefs (constructivist and traditional) concerning science education goals, their roles and their students' roles within teaching and learning science through STS and concerning teaching/learning science through STS. The findings shed light on the relationship between teachers' beliefs and their practises. Lastly, the study revealed a number of factors that caused inconsistency between teachers' beliefs and their practices.
\end{abstract}

Key words: Science Technology and Society STS, Teachers' Beliefs and Practices, Science Teacher Education

\section{Introduction}

\section{Aims of Science Education}

A major goal of education is, or should be, to improve the quality of human existence. An essential part of this goal is the promotion of rational ways in which citizens can influence the conduct and direction of human affairs and can live in a democratic society (Longbottom \& Butler, 1999; Quicke, 2001; Ratcliffe \& Grace, 2003). In democratic societies, the quality of the decision made by the laity is of fundamental importance. Lay people's abilities to promote their point of view on socio-scientific issues are therefore significant. In this respect, Longbottom \& Butler (1999) argue that these assumptions link education in general and science education in particular. Quicke (2001) argues that the primary justification for teaching science to all children is that it should make a significant contribution to the advancement of a truly democratic society. In other words, the changes in current society lead to changes in the role of education in general, and in science education in particular.

Science education is the production of citizens who are creative, critical, analytical, and rational. For this reason, science for citizenship has been discussed as an important goal of science education (Kolstoe, 2001; Ryder, 2002; Ratcliffe \& Grace, 2003; Osborne, 2010). In this respect, Longbottom and Butler (1999) refer to science education that should be designed

\footnotetext{
*Correspondence Author: Phone: +44(0) 1392722842;

E-mail: n.mansour@ex.ac.uk
}

Fax: +44(0) 1392724792

mansournasser@hotmail.com

ISSN: 1306-3049, C2010 
for the general population rather than for a specialist group of future scientists, and that should lead to empowerment in some general sense of giving citizens more control or decision-making ability. To do this, Cross and Price (1999) refer to science education should give pupils a basis for understanding and for coping with their lives. They should be given applications and effects of science in their personal and social life. Ryder (2002: 639) argues that knowledge about science cannot be decontextualized; it is only meaningful when elaborated in specific science contexts. A weakness in existing school science curricula is the presentation of the concepts and relationships of science (knowledge in science) without any reference to the ways in which these ideas were developed (knowledge about science).

The National Science Foundation (NSF) Advisory Committee for Science Education recommended that the traditional approach to science education in science be rethought with more 'emphasis on the understanding of science and technology by those who are not and do not expect to be professional scientists and technologists' (Hurd, 1998). The implication is that notions of scientific literacy should be embedded in contexts that promote a socially responsible and competent citizen (Hurd, 1998). For Jenkins (1999) citizens need to be 'scientifically literate' in order to be able to contribute to decision-making about issues that have a scientific dimension, whether these issues are personal (e.g. relating to medication or diet) or more broadly political (e.g. relating to nuclear power, ozone depletion or DNA technologies).

In the study of the National Specialised Councils (NSC) of Egypt on Science Education for the 21st Century (NSC, 1999), it is clearly stated that science education should aim to:

- provide students with scientific and creative thinking;

- help students to be aware of the massive scientific and technological progress;

- improve environmental behaviour for students;

- help students to understand the nature of science and use scientific processes such as observation, interpretation and conclusion;

- emphasise effective aspects in science teaching to provide students with scientific attitudes and an appreciation of science and scientists;

- look at science from a comprehensive integrated viewpoint, and not as separated subjects (i.e. physics, chemistry, and biology).

From the above discussion, the main aim of Science education in Egypt or worldwide is to prepare young people to contribute as 'scientifically literate citizens' to shaping the world in which they will live. Therefore, science for citizenship is an important educational goal (Jenkins, 1999; Duggan \& Gott, 2002; Hurd, 1998; Longbottom \& Butler, 1999; Kolstoe, 2001). This is a challenge for school science education. This raises questions regarding how science education can prepare students as citizens. This is what the next section will discuss.

\section{STS for Citizenship}

As future citizens, students have the enormous responsibility of making decisions that require an understanding of the interaction of science and technology and its interface with society. The Science-Technology-Society (STS) movement has been strongly identified with meeting this goal but despite its benefits, putting theory into practice has, so far been difficult (Wiesenmayer \& Rubba, 1999; Ryder, 2002; Yetişir \& Kaptan, 2008). In response to the pressing needs of modern societies, it has been argued that science education should pay more attention to the science, technology and society (STS) interface (Eijkelhof \& Lijnse, 1988). In all science programmes that have been identified as 'exemplary' in the National Science Teachers Association (NSTA) 'search for Excellence programme', there was an overt effort by science teachers to help students develop into scientifically literate citizens. One of these 
programmes accepted by NSTA was the Project Synthesis (Ost \& Yager, 1993). Scholars have argued that inclusion of socio-scientific issues through the Science, Technology, and Society (STS) movement in the science curriculum will help in developing the scientifically literate citizen (Wiesenmayer \& Rubba, 1999; Kolsto, 2001; Ryder, 2002; Dimopoulos \& Koulaidis, 2003; Solomon, 2004). Moreover, NSTA refers to STS issues as the best way of preparing young people for citizenship. This is clear in NSTA's definition of STS:

"Basic to STS efforts is the production of an informed citizenry capable of making crucial decisions about current problems and taking personal actions as a result of these decisions. STS means focusing upon current issues and attempts at their resolution as the best way of preparing people for current and future citizenship roles" (cited from: Ost \& Yager, 1993, 282).

STS has been called the current mega-trend in science education (Yager, 1993). Others have called it a paradigm shift for the field of science education (Hart \& Robottom, 1990). The primary objective of an STS education is to present contextual understanding of current science and technology and provide students with the intellectual foundations for responsible citizenship (Aikenhead, 2004; Yetişir \& Kaptan, 2008). In their study, Ramsey \& Hungerford (1989) and Wiesenmayer \& Rubba (1999) showed that an STS issue investigation with an action instructional model that addresses each of the four STS goal levels is crucial in promoting citizenship actions on STS issues. Within STS in science education, the emphasis on the interconnections between science and society has entailed a focus on science-related social issues. It has been argued that to empower the students as citizens, there is a need to emphasise STS (Kolstoe, 2001). It is clear that the science education community values the inclusion of a STS approach in science education programmes (Bakar, Bal \& Akcay, 2006; Celik \& Bayrakçeken, 2006, Kaya et al., 2009, Mansour, 2010). Therefore, it is worth to raising a question: what are science teachers' beliefs concerning the STS issues? This is what the next section will focus on.

\section{Science Teachers for STS}

The Association for Science Education (ASE) in its policy statement "Education through Science" (1981), argued that, in planning and developing the curriculum, teachers should show that science can be explored from the viewpoint of its applications, leading to development of an appreciation and understanding of the ways in which science and technology contribute to the worlds of work, citizenship, leisure and survival. To implement STS in science education, the training and psychological preparation of the teaching force must be considered (Jegede, 1988). According to Za'rour (1987), the unfamiliarity of teachers with the required teaching models and approaches could hinder the introduction of STS education in schools. Similarly, Rubba (1991) suggests that, STS has not attained the level of implementation recommended by NSTA because the majority of the science teachers are not prepared to teach STS. Therefore, before STS teaching practices can be fully developed and put into practice appropriately, science teachers' beliefs and values about science education must be restructured in such a way that, they can fully appreciate what the notion of responsible citizen action on STS issues as a goal of a school science education.

Another barrier for implementing STS in the class (Aikenhead, 1984) is the socialization process that science teachers go through during their preparation in the university. When studying science at university, teachers experience a process of socialization into a discipline (Barnes, 1985; Ziman, 1994). During experience, teachers developed deepseated values about science teaching (Aikenhead, 1984; Pedretti \& Hodson, 1995; Bakar, Bal \& Akcay, 2006; Kaya et al., 2009). Aikenhead (2000) mentions that pre-service education socializes science teachers to believe that their responsibility is to socialize their students into 
a specifically scientific discipline. Therefore, to implement an STS science course successfully, from a teacher's point of view, the best way to initiate students into a discipline is the same way the teacher was initiated (Aikenhead, 1984). Aikenhead (2000) emphasised change the deep-seated, personally cherished values of a number of teachers. In addition to that change, teachers must add new methods to their repertoire of instructional strategies. A new routine of instruction is best learned from fellow teachers who have practical credibility.

Science teachers are the most important key in shifting toward STS education. Therefore, for a successful shift to occur, a science teacher has to have a very complete understanding of what STS education is about and the philosophy behind it. They also need support and help from other people involved in education (Mansour, 2009). A successful plan of action will involve few cleverly selected teachers chosen to go through an intense inservice experience. These teachers then become in-service leaders in their own regions of the country, passing on their leadership expertise to other teachers who repeat the in-service process in their own communities. An example of this approach in preparing STS teachers is presented by Pedretti and Hodson's study (1995). Pedretti and Hodson conducted a one-year study with six science teachers who were positively predisposed to STS science. The aim was to produce usable curriculum materials through teacher ownership and understanding, all organized around an action research group. Pedretti and Hodson documented teachers' increased understanding in terms of the nature of science, developing curriculum materials, personal and professional development, and collaboration. In addition, participants reaffirmed many of their personal theories and practices.

Mansour (2007) refers that science teachers state that the science disciplinary background has not prepared them for STS. An undergraduate education in a science discipline rarely allows students to be aware of the controversy in pure science itself, and its patterns of teaching and learning do not usually include discussion of the merits of arguments or debating about the quality of the empirical evidence or the concepts on which this is based. Through the findings of his case study with 5 science teachers in the Prairie high school to explore the personal reasons, beliefs and dilemmas underlie their decision; Aikenhead (1984) suggested three requirements so the teacher could reflect the NSTA's 1982 position statement supporting a science-technology-society approach to science teaching. These requirements are: (1) an alteration in the teachers' values concerning valid science content, (2) an evaluation of socialising function of their new courses, and (3) a reformulation of the practical holistic decision-making system that currently supports and sustains them on a day to day basis.

The success of science education reform depends on the teachers' ability to integrate the philosophy and practices of current programmes of science education reform with their existing philosophy (Bybee, 1993, Mansour, 2007; 2009). After reviewing the research, Fang (1996) pointed out that practice could be consistent with a teacher's beliefs. Pajares (1992) supported the notion that teachers' beliefs influence their perceptions, which in turn affect their behaviours in the classroom. Thus, when considering the STS approach to science education, teacher beliefs about STS implementation require attention (Carroll, 1999; Yetişir \& Kaptan, 2008; Mansour, 2009a, 2010). Without this attention, negative beliefs concerning STS implementation and inquiry learning could defeat the reform movements emphasising STS.From that point, setting up the Egyptian knowledge society or implementing the national standards for education of Egypt (NSEE) in general, or implementing STS on the Egyptian science curricula based on the contribution of teachers, their convincing with or beliefs about these innovations (Mansour, 2009, 2010). Noss and Hoyles (1996), for instance, argue that the implementation of any innovation, which fails to take account of teacher and the teachers' work situation as mediators of the innovation, is doomed to fail. Therefore it is essential to 
take Egyptian teacher's beliefs into account Thus, to understand genuinely Egyptian teachers beliefs, we should investigate: science teachers' beliefs and practices about the importance of science, Technology, and Society (STS) related issues, the science teachers' knowledge of the STS issues, the importance of integrating the STS issues in the science curricula, and the source of knowledge of the issues.

\section{Research Questions}

The research illuminated these questions;

1. What are the beliefs that science teachers in Egypt hold about the relationship between science, technology and society?

2. What are the beliefs that science teachers in Egypt hold about teaching/learning science through STS Education?

3. How far do science teachers' classroom practices reflect their beliefs about STS?

\section{Sample}

A total of 162 Egyptian preparatory science teachers responded to the questionnaire. This sample included both sexes: eighty-seven (53.7\%) were female science teachers and seventy-five $(46.3 \%)$ were male science teachers. The teachers ranged from 27 to 48 years old, with a mean age of 46. Some of the questionnaire sample $103(63.6 \%)$ had bachelor's degree in Biology Education and the other 57 (35.2\%) had bachelor's degree in Physics and Chemistry education. Only two teachers had bachelor in Science (Chemistry). In terms of teaching experience, respondents were divided up into three experience groupings: newly qualified (from 1 to five years), semi-experienced (from 6-10) and experienced (11 and more). 31 teachers $(19.1 \%)$ are newly qualified have taught under 6 years, 64 semi-experienced teachers have taught from 6-10 years, and 67 experienced teachers have taught over 10 years. Grouping teachers this way might reveals changes in beliefs about STS due to teaching experience amongst teachers. It is indicated that experienced teachers represent a majority in the sample. Concerning qualifications after bachelor degree, the majority of the questionnaire sample had bachelor degree (139 teachers, $(85.8 \%), 4$ teachers had general diploma in education (2.5\%), 16 had specialised diploma in education $(9.9 \%)$, and three teachers had master degree in education. Regarding the school locations that teachers work in, the majority of the questionnaire sample worked at suburban schools (66 teachers, 40.7\%), 55 (40.7\%) teachers worked at urban schools, and 41(25.3\%) worked at rural schools.

\section{Data Collection}

A questionnaire entitled Teacher's beliefs about Science, Technology and Society (STS) Education was devised based on the review of relevant literature (e.g. Aikenhead \& Ryan, 1989; Bybee \& Mau, 1986; Levitt, 2001; Poulson et al., 2001; Rubba \& Harkness, 1993; Tsai, 2002). The questionnaire consisted of 29 items included 27 closed- ended questions and two open-ended questions and were developed to obtain information in four major areas:

1. Personal information included the respondent's age, gender, experience, academic background in education and science, position in school and subjects taught as well as the type of school in which they were employed.

2. The second area 'teacher's perceived beliefs and practices about ScienceTechnology-Society (STS)' included:

- Beliefs about the relationship between science and technology (BAST) (Items 1-4),

- Beliefs about the relationship between science and society (BASS) (Items 5-8),

- Beliefs about the relationship between technology and society (BATS) (items 9-13), 
- And item 14 which measures the interaction between Science-Technology-Society (STS). The question was: There are three terms 'science', 'technology' and 'society'. Can you use the arrows to indicate what do you think about the relationships between them? The arrows may be $\longleftrightarrow$ or $\longrightarrow$.

For example:

$\mathrm{A} \longrightarrow \mathrm{B}$ indicates that $\mathrm{A}$ influences on $\mathrm{B}$

$\mathrm{A} \longleftrightarrow \mathrm{B}$ indicates that there is interactive relationship between $\mathrm{A}$ and $\mathrm{B}$.

3. The third area 'teacher's perceived beliefs and practices about teaching science through STS issues' included:

- Beliefs about teachers and students roles in teaching/learning STS (BATSR) (Items $15-21)$

- Beliefs about teaching and learning STS (BATL-STS) (Items 22-28)

4. The fourth area 'factors perceived to influence the consistency between teachers' beliefs and practices included an open-ended question "why they have difficulty practicing their educational beliefs regarding STS in the classroom".

\section{The Format of The Questionnaire}

- The format of the questionnaire was a combination of Likert-type items, and openended items. The Likert-type items were converted to numerical rating for the purpose of statistical treatment. Each item of the questionnaire measures two dimensions: Dimension one which assessed teachers' beliefs. Each item constitutes a statement, which is followed by a five-point Likert scale ranging from (1) strongly disagreed to (5) strongly agreed. The negative statements were scored in reversed order,

- Dimension two which assessed to what extent teachers were able to put their beliefs into practice. Each item constitutes a statement, which is followed by a three-point Likert scale ranging from (1) not practiced to (3) practiced. The negative statements were scored in reversed order (for examples see Appendix A).

The questionnaire was translated from Arabic into English for the purpose of publication. Two educators specialised in English language looked at the translation to be sure that both Arabic and the English versions are identical. The final questionnaire required a number of revisions before it reached a level of clarity and detail which was judged as adequate by the review panel of experts consisting of:

- The regional science inspector and science consultant

- Lecturers in science, science education and research methods.

\section{Reliability of The Questionnaire}

Cronbach's coefficient alpha was used to calculate the internal consistency coefficients of the items included in the scales in part one of the questionnaire. Results of the reliability analysis showed that the items in these scales had a satisfactory discriminating power. Reliability coefficient alpha obtained for Beliefs about Science and Technology BAST scale was 0.75 , for Beliefs about Science and Society BASS scale was 0.67 , and for Beliefs about Technology and Society BATS scale was 0.63 . Results of the reliability analysis of the items of the two scales 'Beliefs about Teacher/student roles BAT/SR scale and beliefs about Teaching and Learning BATL-STS scale' in part two had a high internal consistency. Reliability coefficient alpha obtained for Beliefs about Science Education Goals BASEG 
scale was 0.64, Beliefs about Teacher Role BATR scale was 0.69 and Beliefs about Teaching and learning STS BATL-STS scale was 0.60.

\section{Factor Analysis}

Exploratory factor analysis was conducted on each set of the items under each scale. As shown in Table 1, The Kasier-Meyer-Okklin (KMO) values for sub -scales BAST, BASS, BATS, BATSR-STS, and BATL-STS were $0.75,0.63,0.67,0.71$ and 0.61 sequentially exceeding the recommended value of 0.6 (Pallant, 2001) and the Barlett's test of shpericity reached statistical significance supporting the factorability of the correlation.

Table 1. The Kasier-Meyer-Okklin (KMO) values for sub-scales BAST, BASS, BATS, BATSR-STS, and BATL-STS

\begin{tabular}{llllll}
\hline scale & Items & $\begin{array}{c}\text { Kaiser-Meyer-Olkin Measure of } \\
\text { Sampling Adequacy }\end{array}$ & Bartlett's Test of Sphericity & df & Sig. \\
\hline BAST & $1-4$ & 0.75 & 144.857 & 6 & 0.00 \\
\hline BASS & $5-8$ & 0.63 & 104.766 & 6 & 0.00 \\
\hline BATS & $9-13$ & 0.67 & 145.715 & 6 & 0.00 \\
\hline BATSR-STS & $15-21$ & 0.71 & 273.356 & 21 & 0.00 \\
\hline BATL-STS & $22-28$ & 0.61 & 283.510 & 28 & 0.00 \\
\hline
\end{tabular}

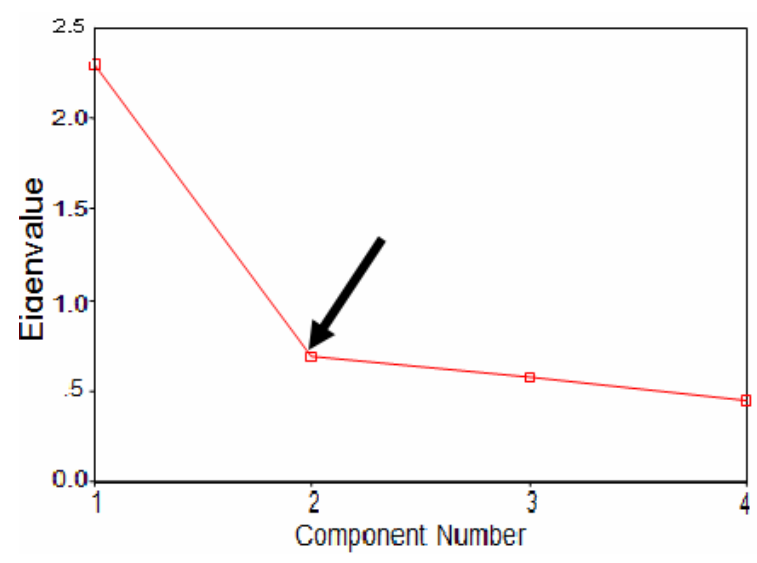

Figure 1. Scree plot for BAST scale

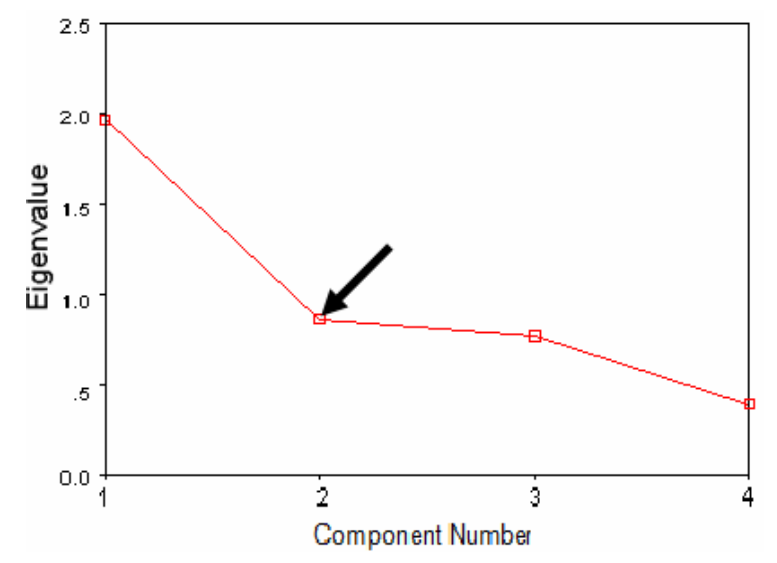

Figure 2. Scree plot for BASS scale 


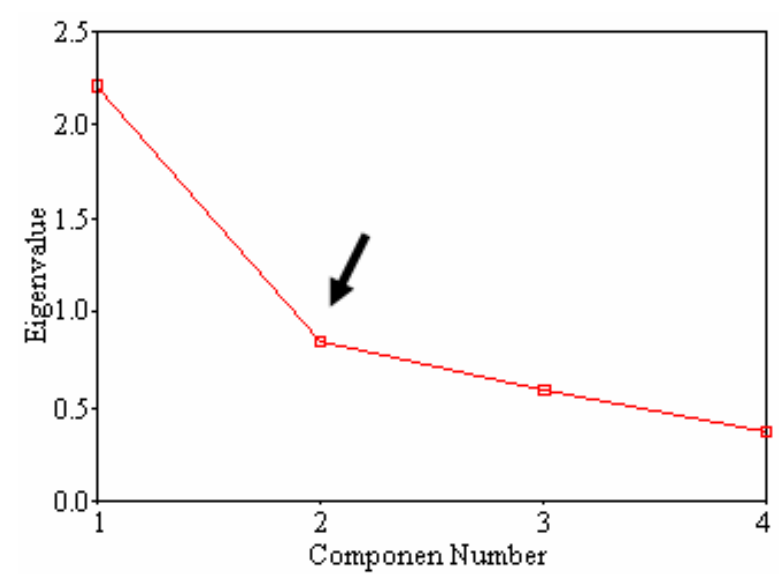

Figure 3. Scree plot for BATS scale

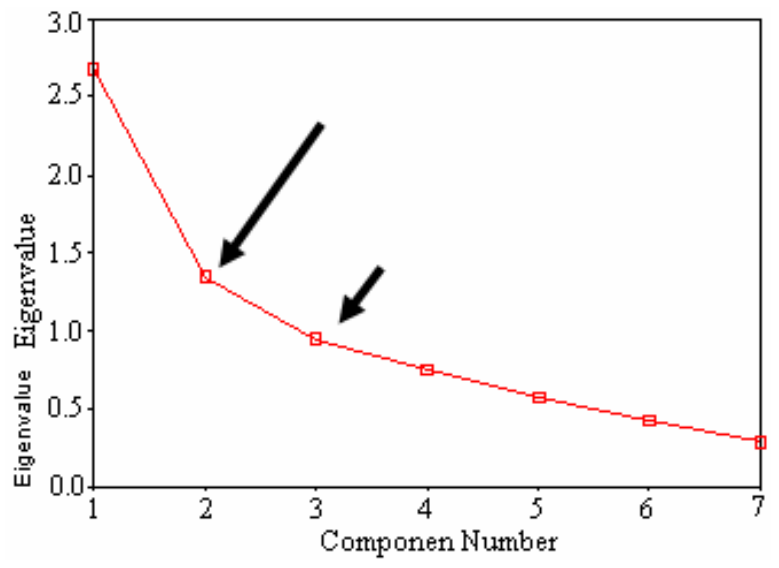

Figure 4. Scree plot for BAT/SR scale

An inspection of the scree plots for scales BAST, BASS, and BATS sequentially shown in Figures 1, 2 and 3revealed a clear break after the first component. Principles components analysis for scales BAST, BASS, and BATS revealed the presence of just one component with eigenvalues exceeding 1 . Moreover, the component matrix shows that only one component extracted and the items of each scale load quite strongly (above 0.4) on that component.

Factor analysis of items (15-21) of scale (BAT/SR) revealed the presence of two factors with eigenvalues of greater than 1.0, explaining $57.46 \%$ of the total variance. Examination of the scree plot (see Figure 4) indicated that a two-factor solution would be appropriate. Moreover, examination of the factor loadings of the component matrix revealed that the 7 items load quite strongly on two factors. The range of these factor loadings was (0.64-0.87). The content of these items were used to interpret the two factors. Factor one was interpreted as teachers' traditional beliefs regarding teachers and students roles in teaching and learning STS. Factor two was interpreted as teachers' constructivist beliefs regarding teachers and students roles in teaching and learning STS.

Factor analysis of items (22-28) of scale (BAT/LSTS) revealed the presence of two factors with eigenvalues of greater than 1.0 , explaining $53.10 \%$ of the total variance. The scree plot (see Figure 5) suggested that a two-factor solution would be appropriate. Examination of the factor loadings of the component matrix revealed that the 8 items load quite strongly on two factors. The range of these factor loadings was $(0.50-0.72)$. The factors were rotated using the normalised varimax rotation method to assist in the interpretation of the extracted factors. Examination of the factor loadings of varimax matrix found stronger loadings ranged from 0.51 to 0.81 and clearer interpretation with a two-factor solution. The content of these items were used to interpret the two factors. Factor one was interpreted as teachers' traditional beliefs regarding teachers and students roles in teaching and learning STS. Factor two was interpreted as teachers' constructivist beliefs regarding teaching and learning STS. 


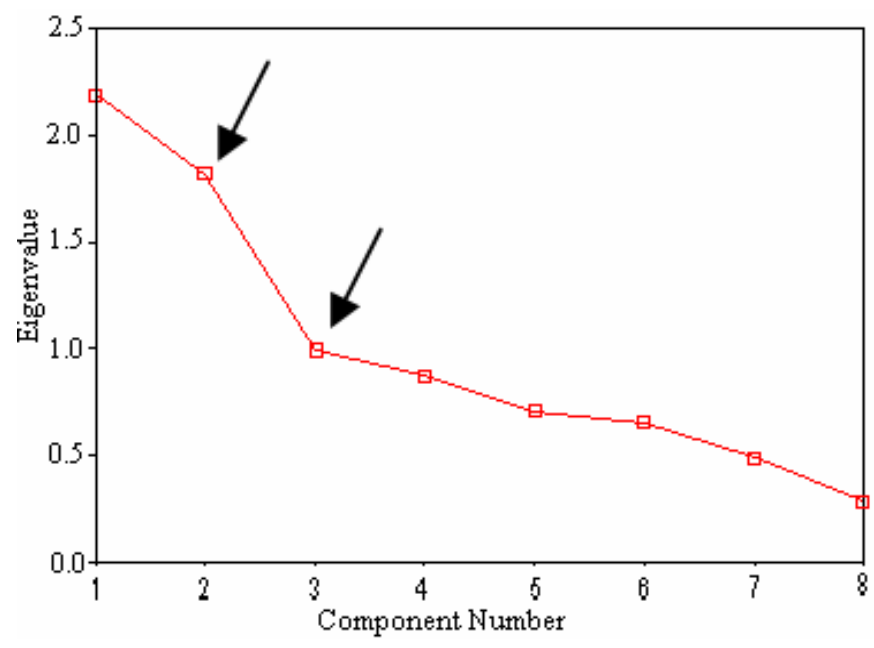

Figure 5. Scree plot for BATLSTS scale

\section{Data Analysis}

The data collected from the questionnaire was carried out using SPSS (Statistical Package for Social Sciences) version 15.0 for windows XP. The statistical analysis was performed included two kinds of statistics: descriptive statistics and inferential statistics. The descriptive statistics used to examine teachers' beliefs included means, standard deviations, frequencies, and percentages. Whereas the inferential statistics included a paired-sample ttest, were used to examine which was the dominant belief (constructivist or traditional) and correlation analyses were used to examine the relationships between teachers' beliefs and practices. Factor analysis was used to explore the structure of the STS questionnaire.

Teachers' responses to open-ended question "what are the barriers that prevent you from teaching science through STS the way you would like to?” were analysed qualitatively.

\section{Research Findings}

To catch teachers' beliefs about the relationship between science, technology and society, they were asked to use a rating scale, 1 (strongly disagree) to 5 (strongly agree), for each item on three sub-scales. Scale one: beliefs about the relationship between science and technology (BAST); Scale two: beliefs about the Relationship between science and society (BASS); Scale three: Beliefs Relationship between technology and society (BATS) and question no. 14 beliefs about the relationship among science, technology and society (BASTS).

Developing this part of the questionnaire depended mainly on "the teachers' beliefs about the interactions among science, technology and society (TBA-STS) items", as developed by Rubba and Harkness (1993). Because TBA-STS are empirically developed items and because these kinds of items do not lend themselves to traditional methods of data analysis except when choices can be collapsed into categories, a special scoring procedure was therefore needed for TBA-STS. In this respect, Aikenhead suggested establishing a threecategory scoring scheme, i.e., Realistic/Has Merit/Naïve (R/HM/N).

- Realistic (R): the choice expresses an appropriate view about the nature of science, technology, and the interactions of these within society.

- Has Merit (HM): while not realistic, the choice expresses a number of legitimate points about the nature of science, technology, and the interactions of these within society. 
- Naïve $(\mathrm{N})$ : the choice expresses a view about the nature of science, technology, and the interactions of these within society that inappropriate or not legitimate.

This study used the categorization of Rubba and Harkness (1993) as a framework or reference for understanding teachers' beliefs about the interactive relationship among science, technology and society, and the results were presented as follows.

\section{Beliefs About Science And Technology (BAST)}

Figure 6 shows that most respondents believed there was a reciprocal relationship between science and technology. Over $90 \%$ stated that technology was very important for science to progress, and also saw that science has a great effect on technology $(95.7 \%)$. According to the Rubba and Harkness categorization (1993), the beliefs expressed about the particular relationship in items 1-4 (i.e., that between science and technology) were distributed across the Realistic (R), Has Merit (H), Naïve (N) categories; in other words, the teachers had mixed views about the relationship between science and technology. On the one hand, a high percentage of teachers expressed realistic views about the relationship between science and technology (e.g., 95.7\% of teachers expressed views about the effect of science on technology, and another $75.9 \%$ of teachers took the view that technology had an influence on science.
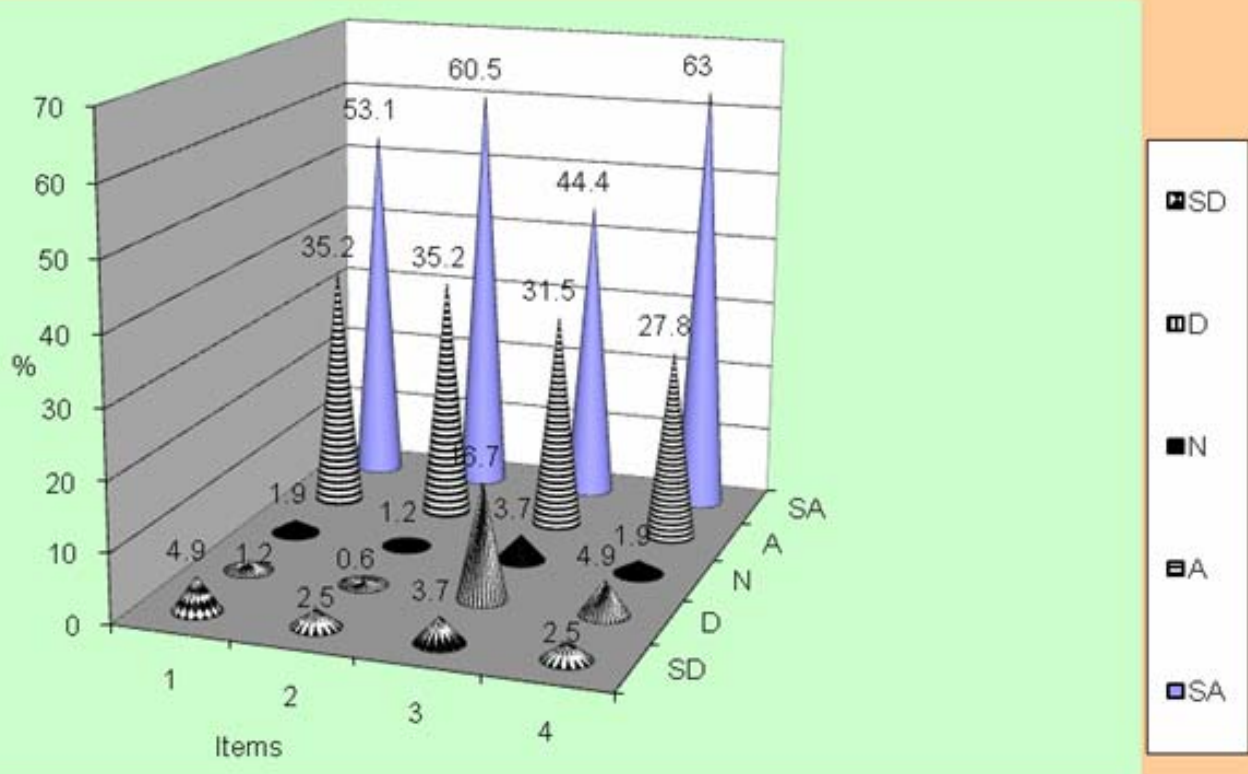

Figure 6. Teachers' Beliefs about Science and Technology

Note: $\mathrm{SA}=$ strongly agree, $\mathrm{A}=$ agree, $\mathrm{N}=$ Neutral, $\mathrm{D}=$ disagree, $\mathrm{SD}=$ strongly disagree, Items are as follows:

1- Technology is the application of science.

2- Science as a body of knowledge does affect technology.

3- Technology does affect science to discover new things.

4- Technology provides tools and techniques for science.

\section{Beliefs About The Relationship Between Science And Society (BASS)}

The majority of the respondents as shown in Figure 7 indicate that they believe that there is an interactive relationship between science and society and each one affects the other. They believe that science has much influence on the society $(84.6 \%)$ than society has on science $(55.3 \%)$. 
Teachers as shown in Figure 7 believe that science and society bushes each other to understand the world and reach the knowledge. They also believe that society bushes science $(82.4 \%)$ more than science $(56.2 \%)$ bushes society to investigate the knowledge. this explains why society is much influenced by science $(84.6 \%)$.

Using Rubba and Harkness (1993) as a framework to understand teachers' beliefs regarding the relationship between science and society, the teachers expressed both Realistic (R) views and Has Merit (HM) views. In other words, the teachers had mixed views about the relationship between science and society. On the one hand, some teachers (84.6\%) expressed realistic views about the affect of science on society and others $(55.3 \%)$ expressed realistic views about the affect of society on science. On the other hand, $56.2 \%$ of teachers expressed views, which were, have merit view in Figure 7. 82.4\% also of teachers expressed views, which were, has merit view.

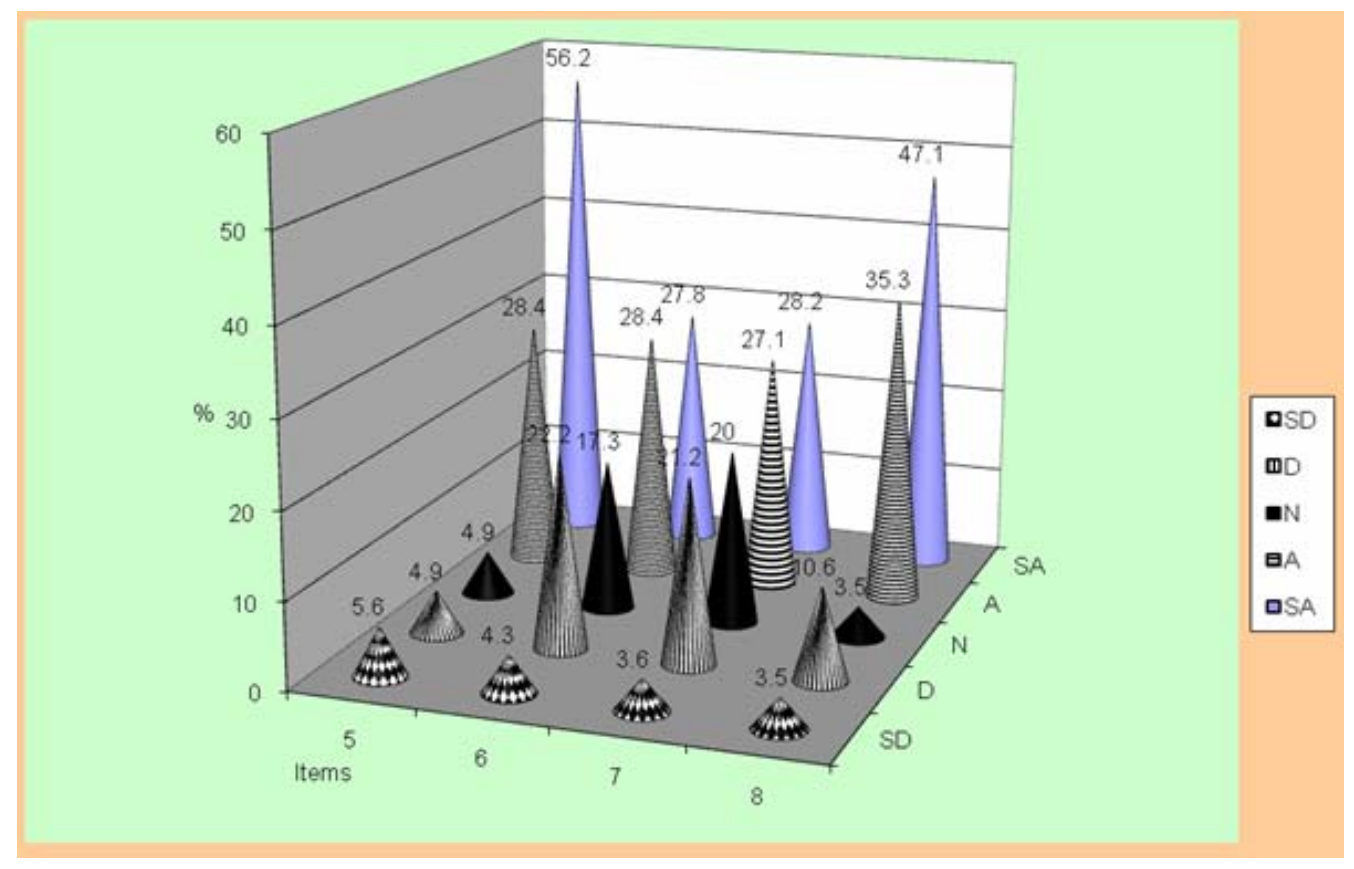

Figure 7. Teachers' Beliefs about Science and Society

Note: $\mathrm{SA}=$ strongly agree, $\mathrm{A}=$ agree, $\mathrm{N}=$ Neutral, $\mathrm{D}=$ disagree, $\mathrm{SD}=$ strongly disagree, Items are as follows:

5- Science does affect society to a great extent.

6- Science stimulates society to seek further knowledge.

7- Society does affect science to a great extent.

8- Society's quest to understand the world stimulates the accumulation of scientific knowledge.

\section{Beliefs About Technology And Society (BATS)}

The majority of the respondents as shown in Figure 8 indicate that they believe that there is an influential relationship between technology and society. More than $80 \%$ stated that technology has a great effect on the progress of the society. At the same time a high percentage of the teachers $(95.7 \%)$ see that the use of technology at Egyptian society is controlled by society traditions, morals, and values. This finding was not surprising in terms of the main characteristic of Egyptian society which is religion-oriented.

However, according to Rubba and Harkness (1993), the beliefs the teachers expressed about the particular relationship in items related to the relationship between technology and society were distributed across the Realistic (R), Has Merit (H), Naïve (N) categories. In other 
words, the teachers had mixed views about the relationship between technology and society. On the one hand, high percentage of the teachers (89.4\%) expressed realistic views about the affect of technology on society; another high percentage of the teachers $(82.1 \%)$ expressed realistic views of the affect of society on technology in Figure 8.

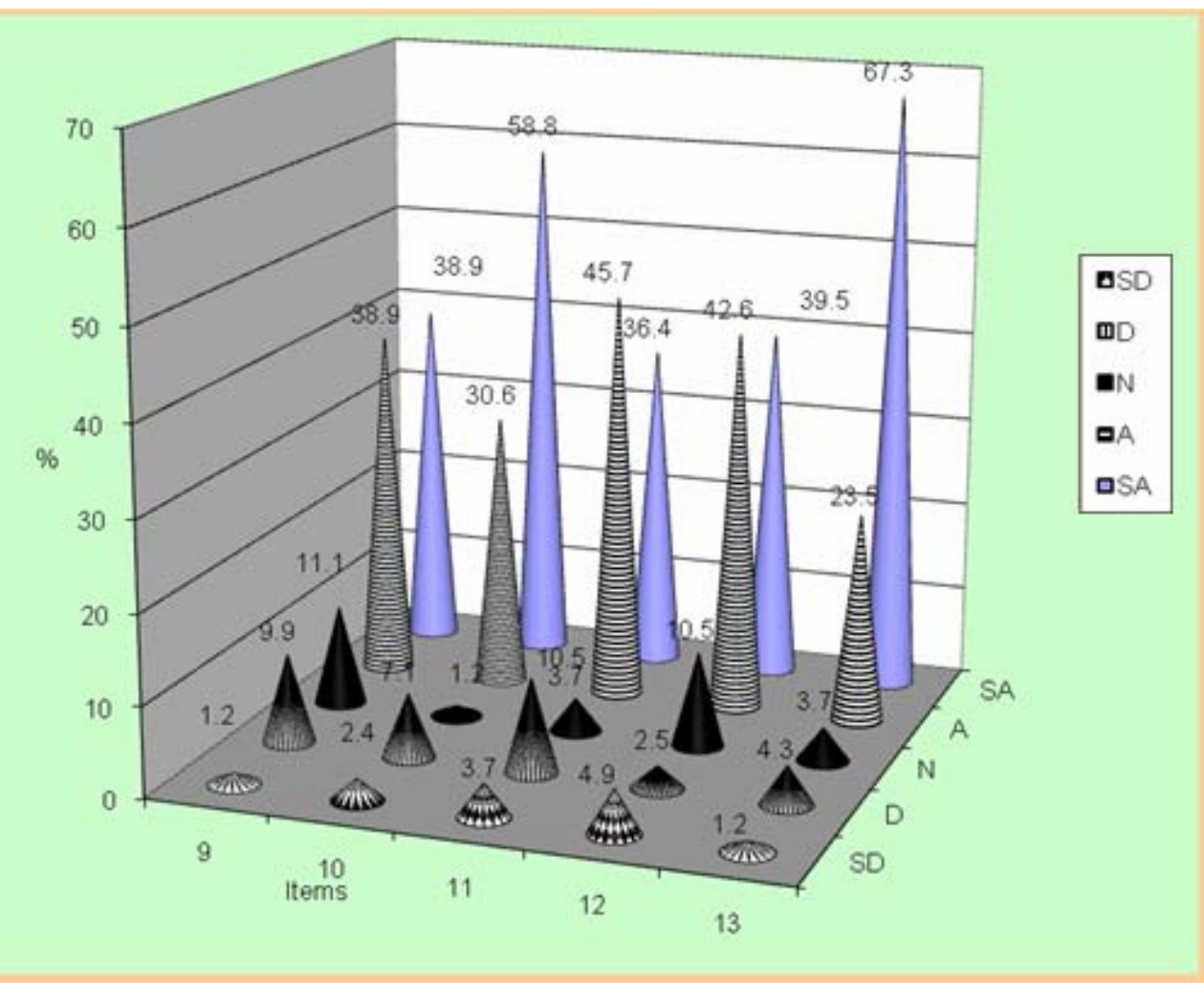

Figure 8. Teachers' Beliefs about Technology and Society

Note: $\mathrm{SA}=$ strongly agree, $\mathrm{A}=$ agree, $\mathrm{N}=$ Neutral, $\mathrm{D}=$ disagree, $\mathrm{SD}=$ strongly disagree, Items are as follows:

9- Technology makes life easier.

10- Technology does affect society.

11- Technology affects society by the way society uses it.

12- Society's needs create demands for technology.

13- Society puts restrictions on the use of technology to control it.

On the other hand, $77.8 \%$ expressed views about the use of technology within the society which were naïve in Figure 8. A little percentage of the teachers (42\%) also expressed views about how society control the use of technology which is considered has merit views.

\section{Beliefs Science, Technology And Society (BASTS)}

For question 14, the teachers were asked to use the three terms 'science', 'technology' and 'society' and the arrows to indicate what do they think about the relationships between science, technology, and society. The results of that question are represented in Table 2. Eight different representations of the interactions of science, technology and society were emerged from teachers' responses.

a) Twenty one teachers (13\%) denoted a linear relationship between science, technology and society. This relationship shows that science affects society through using the technology, which results from applying science. 
b) Three teachers (1.9\%) indicated a linear relationship between science, technology and society. This relationship shows that technology affects society through putting into practice the science which results from technology.

c) Another three teachers $(1.9 \%)$ showed a single dominant relationship. In this representation, these three teachers indicated that 'science' is the dominant factor affecting both technology and society.

d) Forty-two teachers (25.9\%) represented the relationship among science, technology society as a single dominant relationship in which 'society' is the dominant factor affecting both science and technology. Again this was not unexpected result as the qualitative will explain some social factors that can affect teachers' beliefs and practices.

e) Seven teachers $(4.3 \%)$ denoted other single dominant relationship in which 'technology' is the dominant factor affecting both science and society.

f) Twenty five teachers (14.5) indicated a cyclical-linear relationship between science, technology and society. All these teachers saw that the beginning and the end of this cyclic is the science. They believe that science results in technology and this technology in turn has affect on society. Therefore society gives feedback to the scientists to about the resulting of this application of technology in terms of its advantages and disadvantages.

Table 2. Frequency and percentage of teachers' responses on item 14 of the relationship between STS

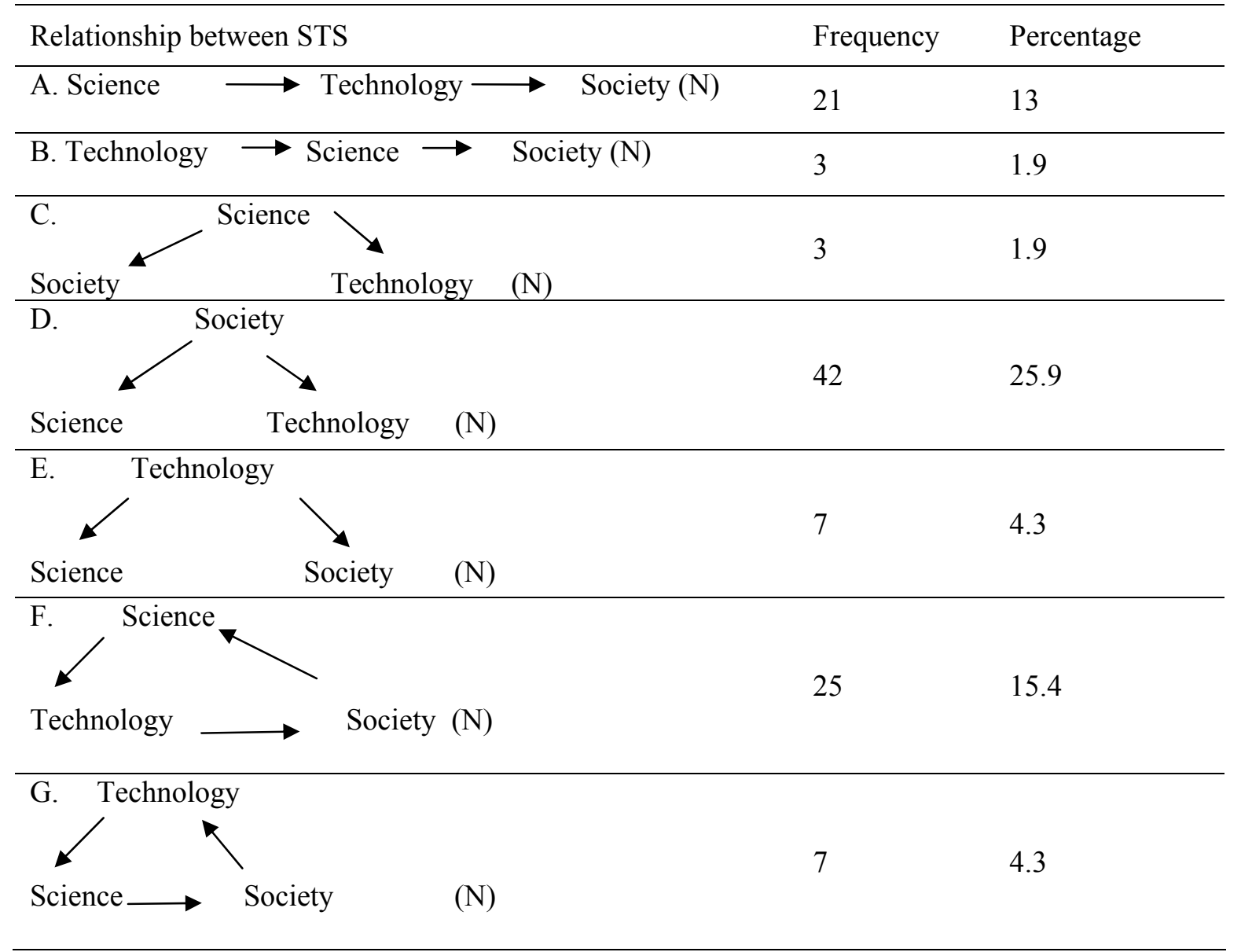




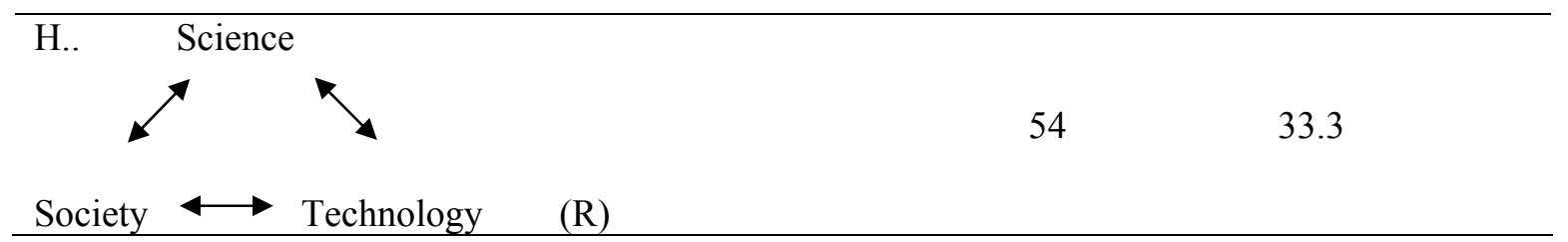

g) Other seven teachers $(4.3 \%)$ indicated a cyclical-linear relationship between science, technology and society. But these seven teachers saw that the beginning and the end of this cyclic is the technology. They believe that new technology results in or affects science and this science in turn has affect on society. Therefore society either forms attitude toward using this technology or gives feedback to the technicians to understand more science

h) Most of the sample teachers (33.3\%) denoted an interactive-cyclic- relationship among science, technology and society. They believe that the three are interrelated as science and technology lead to each other and the society is the ultimate climate of science and technology and each of the three terms takes and gives feedback to the others.

Using Rubba and Harkness (1993) as a reference of understanding teachers' representation of the relationship among science, technology and society, the results in Table 2 shows that the beliefs that teachers expressed about the particular relationship on question 14 were distributed differently across two views; the realistic $(\mathrm{R})$ and naïve $(\mathrm{N})$ categories. On the one hand, high percentage of the teachers $(66.7 \%)$ expressed naïve $(\mathrm{N})$ views on how science, technology and science interact with each other as a system. On the other hand, $33.3 \%$ of the teachers expressed a realistic $(\mathrm{R})$ view about the interactions among science, technology and society.

\section{Findings Related To "Beliefs about teaching science through STS"}

To catch teachers' beliefs about teaching science through STS education, they were asked to use a rating scale, 1 (strongly disagree) to 5 (strongly agree), for each item on two scales. Scale four: Beliefs about the roles teacher/students in teaching/learning STS (BATR), and scale five: Beliefs about teaching/learning STS (BAT/LSTS).

\section{Beliefs About Teachers/Students Roles In Teaching/Learning STS (BATSR)}

Having done the factor analysis of items (15-21), the results revealed two factors one named 'teachers' constructivist views about the roles of teachers/students in teaching/learning STS" and the other named "teachers" traditional views about the roles of teachers/students in teaching/learning STS". As shown in Figure 9 the teachers hold mixed views about the roles of teachers and students on the class during teaching/learning STS. On the one hand, teachers hold constructivist views concerning their roles and their students. For example, they believe that it is the responsibility of the teachers to provide their students with STS learning resources $(82.1 \%)$. The teachers as well believe that they should give the students the opportunity to express their opinions and lead the discussion of STS issues $(77.1 \%)$. The teachers within constructivist views gave importance to students' prior knowledge concerning STS issue under discussion $(61.8 \%)$ and to students' thinking about the relationship among science, technology and society $(86.1 \%)$.

On the other hand, teachers hold traditional views about their roles and their students' roles within STS class. Such as, they believe teachers should determine what and how students should learn STS (64.2\%). Within this traditional orientation, high percentage of the teachers $(93.8 \%)$ believes that their main role is to explain STS issues. Also, most of the 
teachers $(86.4 \%)$ followed this traditional view try to encourage their students by asking the students easy questions to get their attention and keep them listening to the teachers.

A paired-sample t-test was conducted to see whether there is a difference in teachers' beliefs in terms of their responses for both constructivist beliefs about teacher/ student roles subscale and the traditional beliefs about teacher/ student roles subscale.

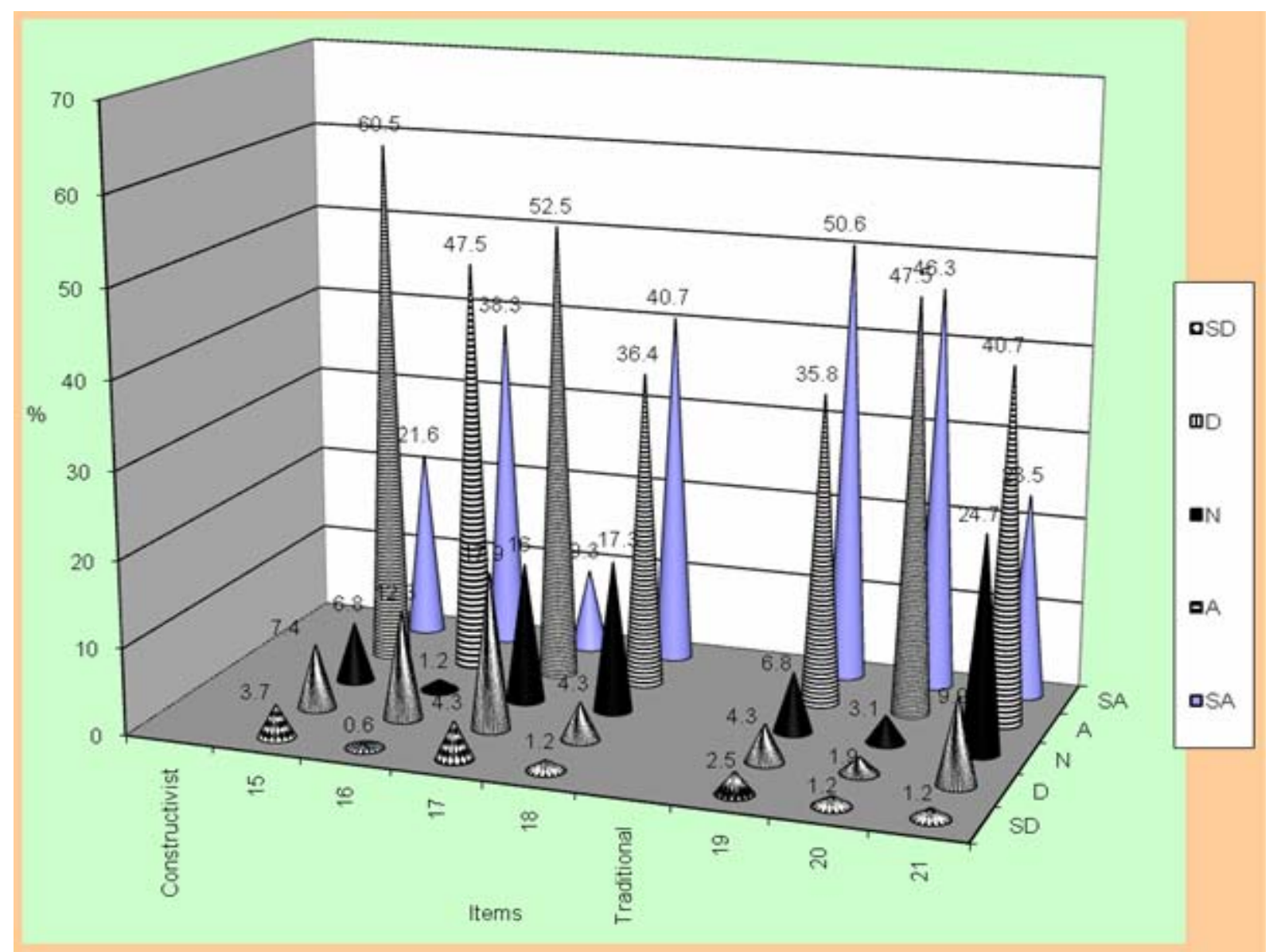

Figure 9. Beliefs about teachers/students roles in teaching/learning STS

Note: $\mathrm{SA}=$ strongly agree, $\mathrm{A}=$ agree, $\mathrm{N}=$ Neutral, $\mathrm{D}=$ disagree, $\mathrm{SD}=$ strongly disagree, Items are as follows:

- Constructivist views

15. Provide opportunities and resources for his students to discuss STS issue.

16. Help students think about their ideas concerning the relationship between STS.

17. Explore students' prior knowledge regarding STS issues

18. Society puts restrictions on the use of technology to control it.

- Traditional views

19. Ask questions about STS that the students could answer quickly.

20. Explain the STS issue.

21. Decide not the students what STS activities are to be done

Table 3. A paired-sample t-test of traditional-constructivist beliefs about teacher/student roles.

\begin{tabular}{llllllll}
\hline & mean & $\mathrm{N}$ & Std. Deviation & $\mathrm{t}$ & $\mathrm{df}$ & Sig. (2-tailed) \\
\cline { 1 - 5 } $\begin{array}{l}\text { traditional beliefs about } \\
\text { teaching/ learning STS }\end{array}$ & 4.25 & 162 & 0.60 & -6.73 & 161 & 0.000 \\
$\begin{array}{l}\text { constructivist beliefs about } \\
\text { teaching/ learning STS }\end{array}$ & 3.87 & 162 & 0.77 & & & \\
\hline
\end{tabular}


As shown in Table 3 there was not a statistically significant difference on teachers' responses and the mean of teachers' traditional beliefs $(\mathrm{M}=4.25, \mathrm{SD}=0.60)$ was higher than that of teachers' constructivist beliefs $(M=3.87, S D=0.77), t(161)=6.73, p<0.0001$. This explained that teachers' beliefs seem to be more traditional regarding their roles and their student's roles on STS class.

\section{Beliefs about teaching/learning STS (BATL-STS)}

Also the factor analysis of items (22-28) came up with two factors. One was related with the constructivist view of teaching and learning and the other one related with the traditional views about teaching and learning. However, the responses of the teachers on the Beliefs about teaching/learning STS scale as shown in Figure 10 indicate that teachers hold positive attitude toward both the constructivist views of teaching/learning STS and traditional views of teaching and teaching/learning STS. On the one hand, most teachers hold beliefs concerning teaching/learning science through STS that are in fairly close alignment with constructivist views.

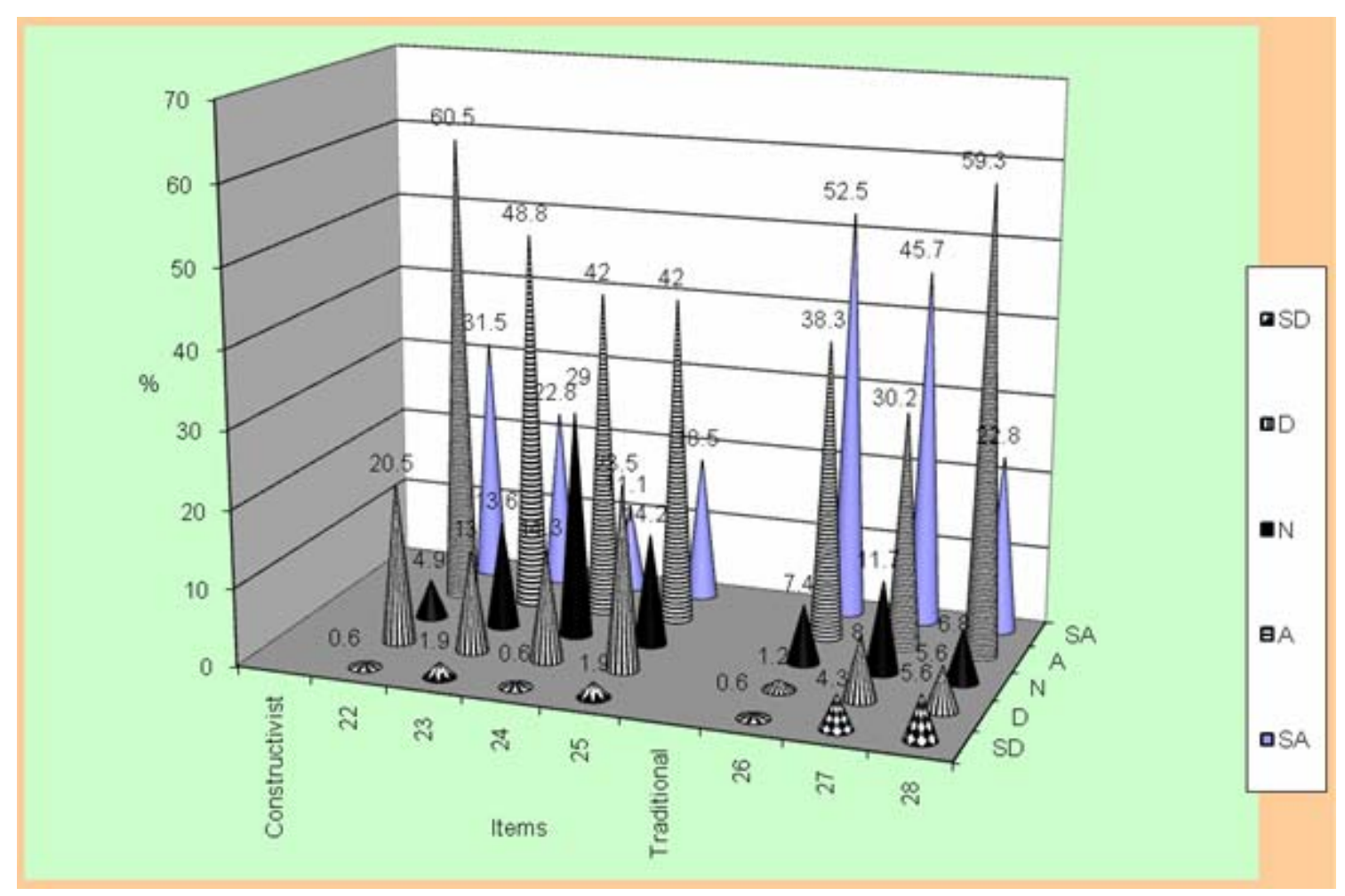

Figure 10. Beliefs about teaching/learning STS (BATL-STS)

Note: $\mathrm{SA}=$ strongly agree, $\mathrm{A}=$ agree, $\mathrm{N}=$ Neutral, $\mathrm{D}=$ disagree, $\mathrm{SD}=$ strongly disagree, Items are as follows: - Constructivist views

15. Different sorts of activities should be used on teaching STS issue.

16. Students should relate the STS issue to their personal experience.

17. Societal dimension is the most important aspect of STS education

18. Science, technological, and societal dimensions should take equal attention in teaching science. - Traditional views

19. Student should learn STS issues as on their textbook

20. It's more practical to give the whole class the same activity, one that can be done in short time.

21. Students need to memorize relevant facts within the STS issues and copy what teachers say. 
For example, high percentage of the teachers $(92 \%)$ believed that it is important to provide more than one source of information so students can see the STS issue from different perspectives and have many inputs. Large numbers of these teachers $(71.6 \%)$ expressed that learners construct knowledge about STS issues based on their prior knowledge related with these issues. Follow the constructivist view; the teachers' responses highlighted the importance of teaching/ learning science from social aspect $(53.1 \%)$ and from different aspects 'scientifically, technologically, and socially' (60.8\%). On the other hand, as can be seen in Figure 10 teachers hold traditional views about teaching/learning science through STS. Such as, $82.1 \%$ of the teachers hold beliefs that students receive mainly knowledge regarding STS issues from what teachers say at the classroom. Also $90.8 \%$ of the teachers highlighted the importance of the students' science textbooks as main sources of teaching/learning STS. In the same vein, 76.2\% emphasised the importance of science aspect more than other aspects within STS education. Because of the time constrain, $75.9 \%$ of the teachers believe that giving all the students the same activity can achieve the learning aims and sort out the time problem.

A paired-sample t-test was conducted to see whether there is a difference in teachers' beliefs in terms of their responses for both constructivist beliefs about teaching/ learning STS subscale and the traditional beliefs about teaching/ learning STS subscale.

Table 4. A paired-sample t-test of traditional-constructivist beliefs about teaching/learning STS

\begin{tabular}{lcccccc}
\hline & mean & $\mathrm{N}$ & Std. Deviation & $\mathrm{t}$ & $\mathrm{df}$ & Sig. (2-tailed) \\
\hline $\begin{array}{l}\text { traditional beliefs about teaching/ } \\
\text { learning STS }\end{array}$ & 14.95 & 162 & 2.66 & & 161 & 0.124 \\
$\begin{array}{l}\text { constructivist beliefs about } \\
\text { teaching/ learning STS }\end{array}$ & 14.48 & 162 & 3.18 & & & \\
\hline
\end{tabular}

As shown in Table 4 there was not a statistically significant difference on teachers' responses but still the mean of teachers' traditional beliefs $(\mathrm{M}=14.95, \mathrm{SD}=2.66)$ was higher that that of teachers' constructivist beliefs $(\mathrm{M}=14.48, \mathrm{SD}=3.18), \mathrm{t}(161)=1.59, \mathrm{p}<0.0001$. This can be explained that the teachers hold mixed traditional- constructivist beliefs regarding teaching/learning STS.

\section{The relationship between teachers' beliefs and their practices}

The main aim of this section is to give an overview of the relationship between teachers' beliefs and their practices in terms of consistency and non-consistency. To achieve this aim, teachers were asked to use a rating scale on two dimensions. Dimension one to assess teachers' beliefs which rating from 5 (strongly agree) to 1 (strongly disagree). and dimension two to assess to what extent teachers are able to put their beliefs into practice which rating from 3 (practice) to 1 (no practice).

As can be seen in Figures 11, 12 and 13 and Table 5 (see Appendix A) teachers had strongly agreement on the items of the scales which measure teachers' beliefs regarding the relationship between 'science and technology', 'science and society' and 'society and technology' much than they did to the counterpart practice items. For example as can you seen in Figures 11, 13 and 14 and Table 5, teachers tended to mark the agreed responses (agree and strongly agree) of items (1-13) of belief scales. The range of teachers' choosing of beliefs items was $(75.9-95.7 \%),(55.3-84.6 \%)$ and $(77.8-89.8 \%)$ in sequentially about the 
relationship between 'science and technology', 'science and society' and 'society and technology'. Comparing with these strong responses to beliefs items, the range of teachers' choosing of practice items was (38.9-49.4\%), (14.2-58\%), and (35.2-58\%) in sequentially for the relationship between 'science and technology', 'science and society' and 'society and technology'.

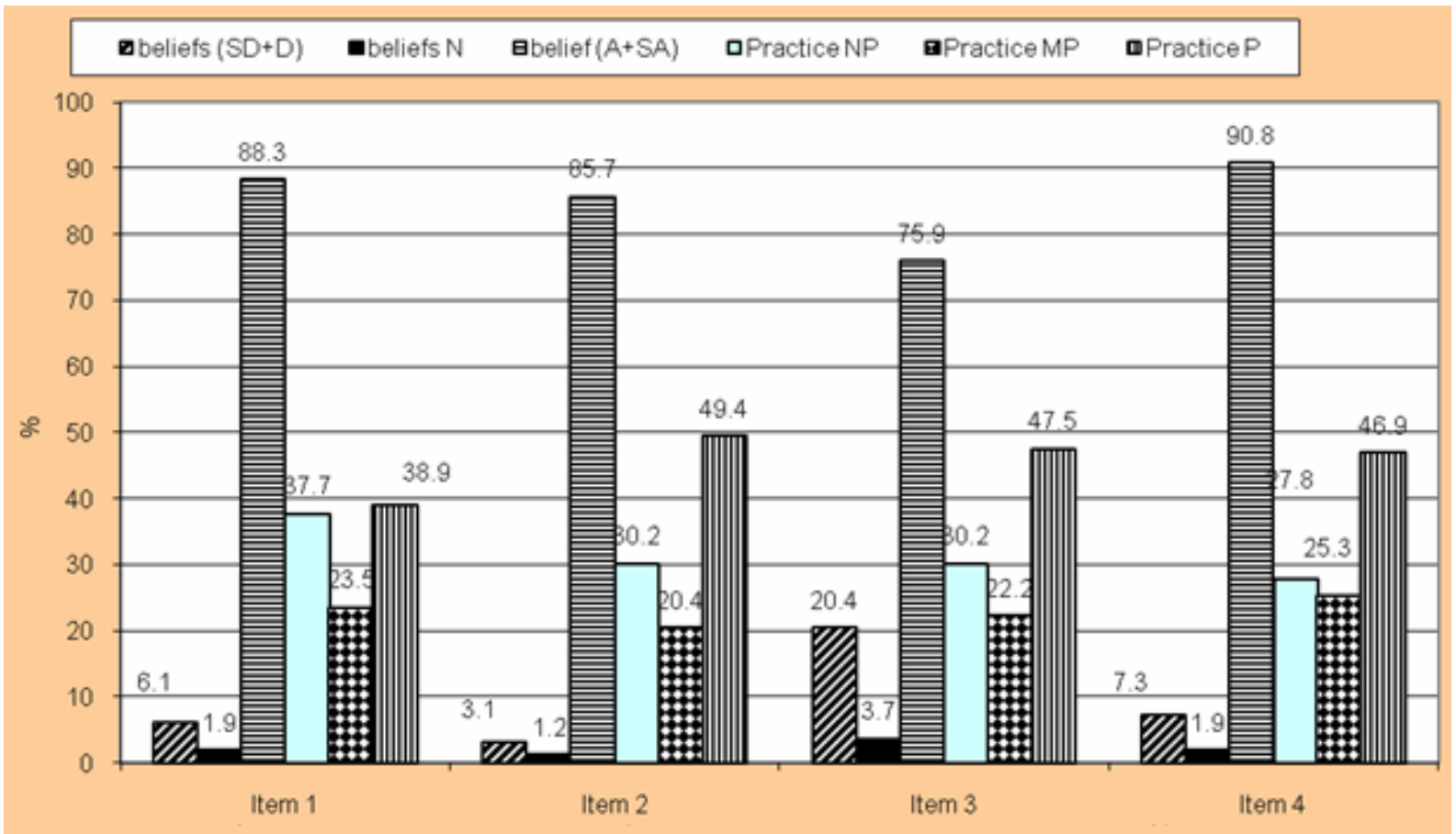

Figure 11. Teachers' Beliefs and practices about science and technology

Note: $\mathrm{A}+\mathrm{SA}=$ agree belief responses, $\mathrm{N}=\mathrm{Neutral}, \mathrm{SD}+\mathrm{D}=$ disagree belief responses, $\mathrm{NP}=$ no practice, $\mathrm{MP}=$ Medium practice, $\mathrm{P}=$ practice Items are as follows:

1- Technology is the application of science.

2- Science as a body of knowledge does affect technology.

3- Technology does affect science to discover new things.

4- Technology provides tools and techniques for science.

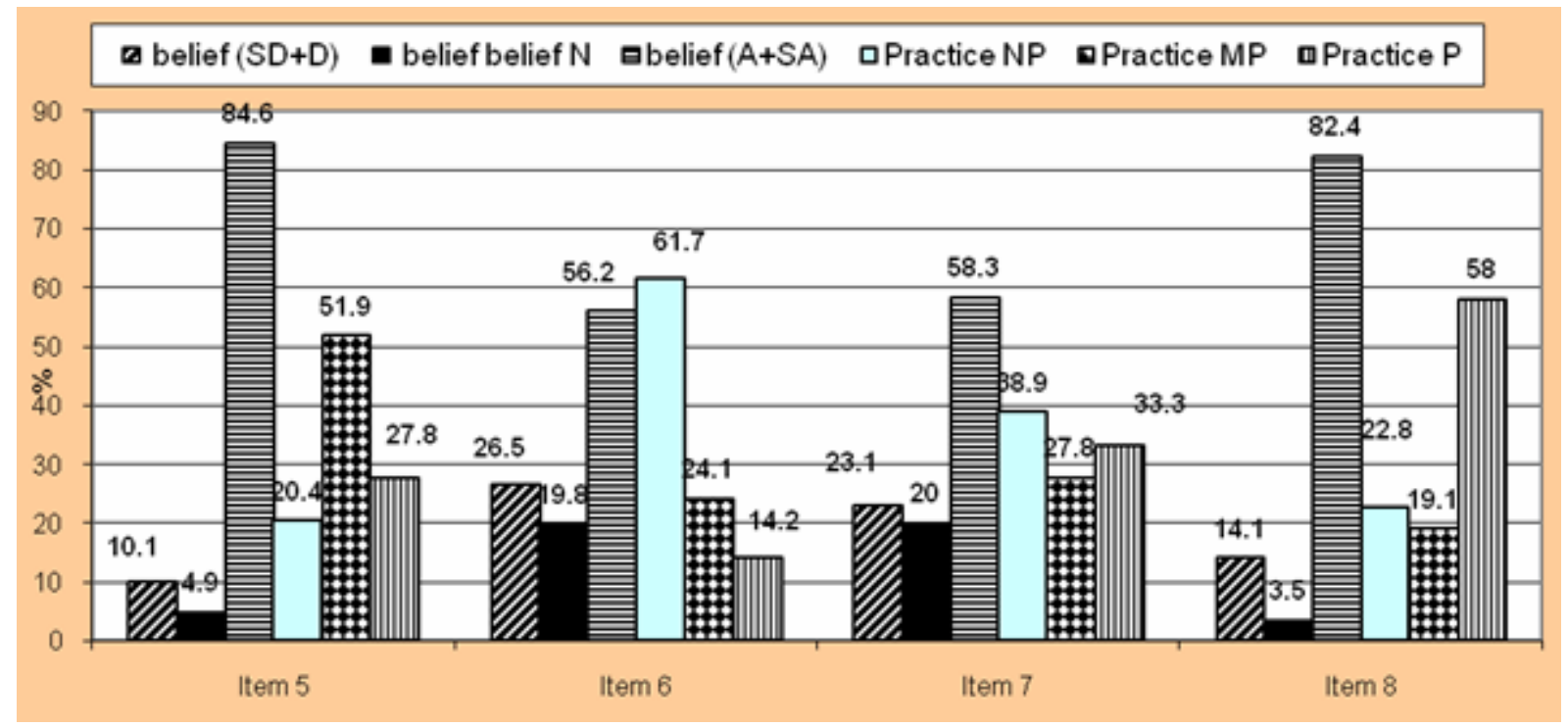


Figure 12. Teachers' Beliefs and practices about science and Society

Note: $\mathrm{A}+\mathrm{SA}=$ agree belief responses, $\mathrm{N}=$ Neutral, $\mathrm{SD}+\mathrm{D}=$ disagree belief responses, $\mathrm{NP}=$ no practice, $\mathrm{MP}=$ Medium practice, $\mathrm{P}=$ practice Items are as follows:

5- Science does affect society to a great extent.

6- Science stimulates society to seek further knowledge.

7- Society does affect science to a great extent.

8- Society's quest to understand the world stimulates the accumulation of scientific knowledge.

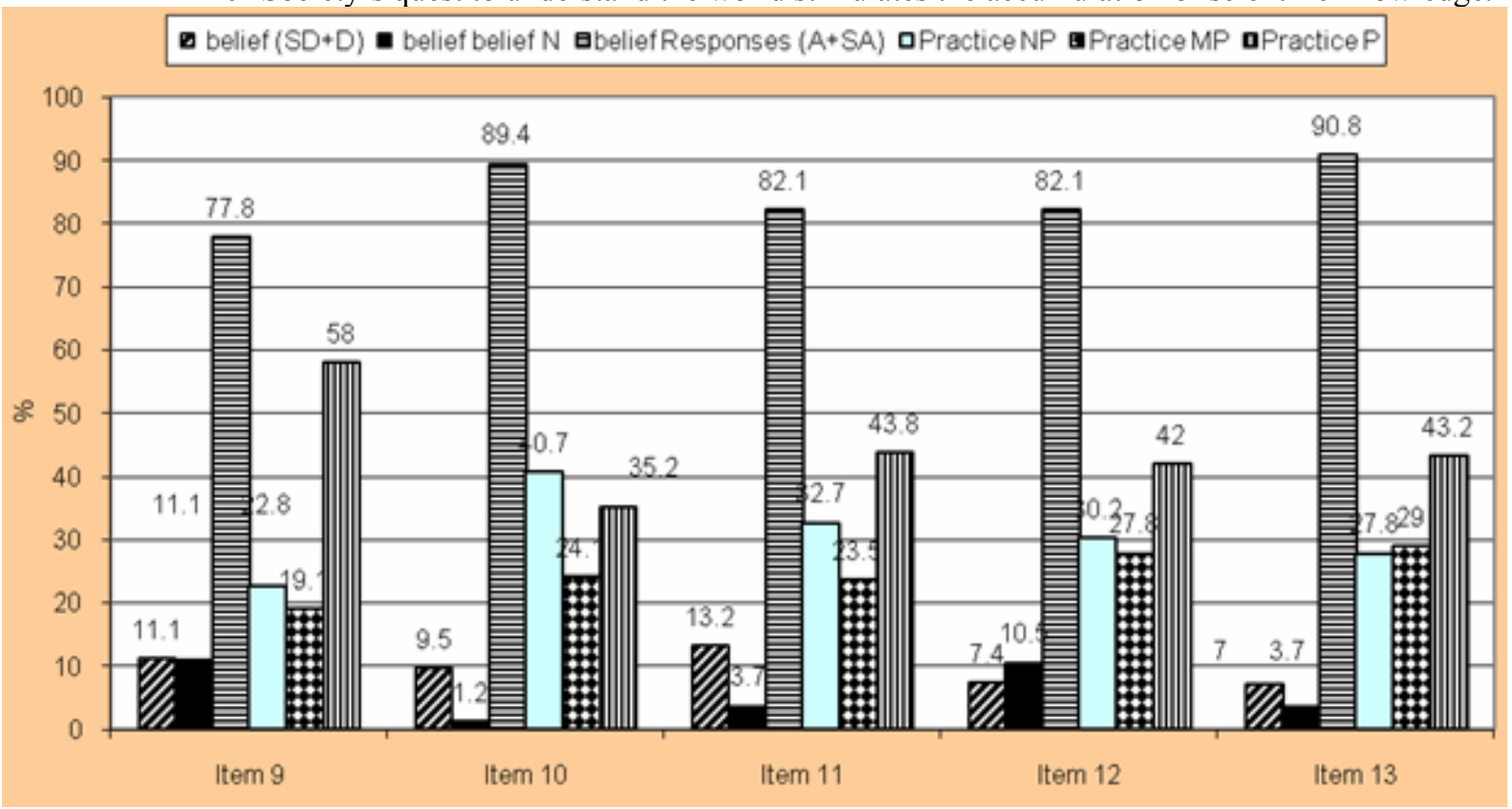

Figure 13. Teachers' Beliefs and practices about Technology and Society

Note: $\mathrm{A}+\mathrm{SA}=$ agree belief responses, $\mathrm{N}=$ Neutral, $\mathrm{SD}+\mathrm{D}=$ disagree belief responses, $\mathrm{NP}=$ no practice, $\mathrm{MP}=$ Medium practice, $\mathrm{P}=$ practice Items are as follows:

9- Technology makes life easier.

10- Technology does affect society.

11- Technology affects society by the way society uses it.

12- Society's needs create demands for technology.

13- Society puts restrictions on the use of technology to control it.

This indicated that there was more than $50 \%$ of the teachers could not put their beliefs in practice. On other words, this maybe gives indication in many cases that there was no consistency between teachers' beliefs and their practices about the interaction relationship among science, technology and society.

As far as the interactive relationship between teachers' beliefs and their practices about teaching/ learning science through STS is concerned, results as shown in Figures 11, 12 and 13 indicated that there were consistencies between teachers' traditional beliefs and their practices. In contrast, there were inconsistencies between teachers' constructivist beliefs and their practices.

Explore students' concerning beliefs and practices about teachers and students' roles, the results as shown in Figure 14 and Table 5 indicted that on one hand, there was a vast disagreement between teachers' responses on constructivist belief items and their counterpart of practice items. As can be seen in Figure 14, 61.8-85.8 percentage of the teachers expressed that the main role of the teachers is to support, help and provide the students with different learning facilities, compared to only (24.1-59\%) of the teachers expressed that they can put these beliefs in practice. On the other hand, as can be noticed in Figure 14 there was consistency between teachers' traditional beliefs and their traditional practices. A vast 
percentage of the teachers (64.2-86.4\%) believed that it is their responsibility to choose the suitable activities, explain in details STS issues, and make evaluation by using easy questions. This indicates that teachers' traditional beliefs were in consistency with their traditional practices.

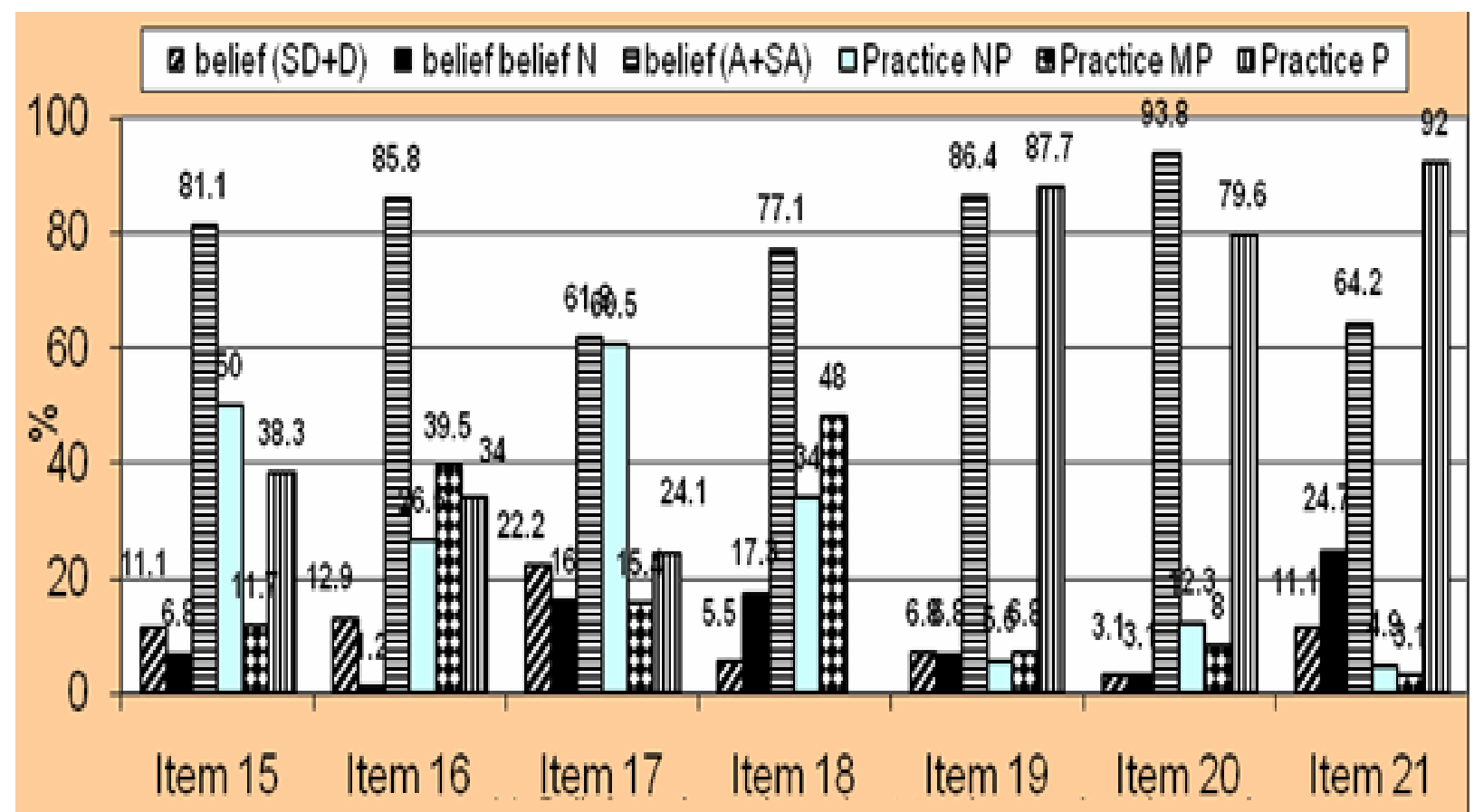

Figure 14. Beliefs and practices about teachers and students' roles

Note: $\mathrm{A}+\mathrm{SA}=$ agree belief responses, $\mathrm{N}=\mathrm{Neutral}, \mathrm{SD}+\mathrm{D}=$ disagree belief responses, $\mathrm{NP}=$ no practice, $\mathrm{MP}=$ Medium practice, $\mathrm{P}=$ practice Items are as follows:

- Constructivist viewss to discuss STS

15- Provide opportunities issue.

16- Help students think about their ideas concerning and resources for his student the relationship between STS.

17- prior knowledge regarding STS issues

18- Society puts restrictions on the use of technology to control it.

- Traditional views

19- Ask questions about STS that the students could answer quickly.

20- Explain the STS issue.

21- Decide not the students what STS activities are to be done 


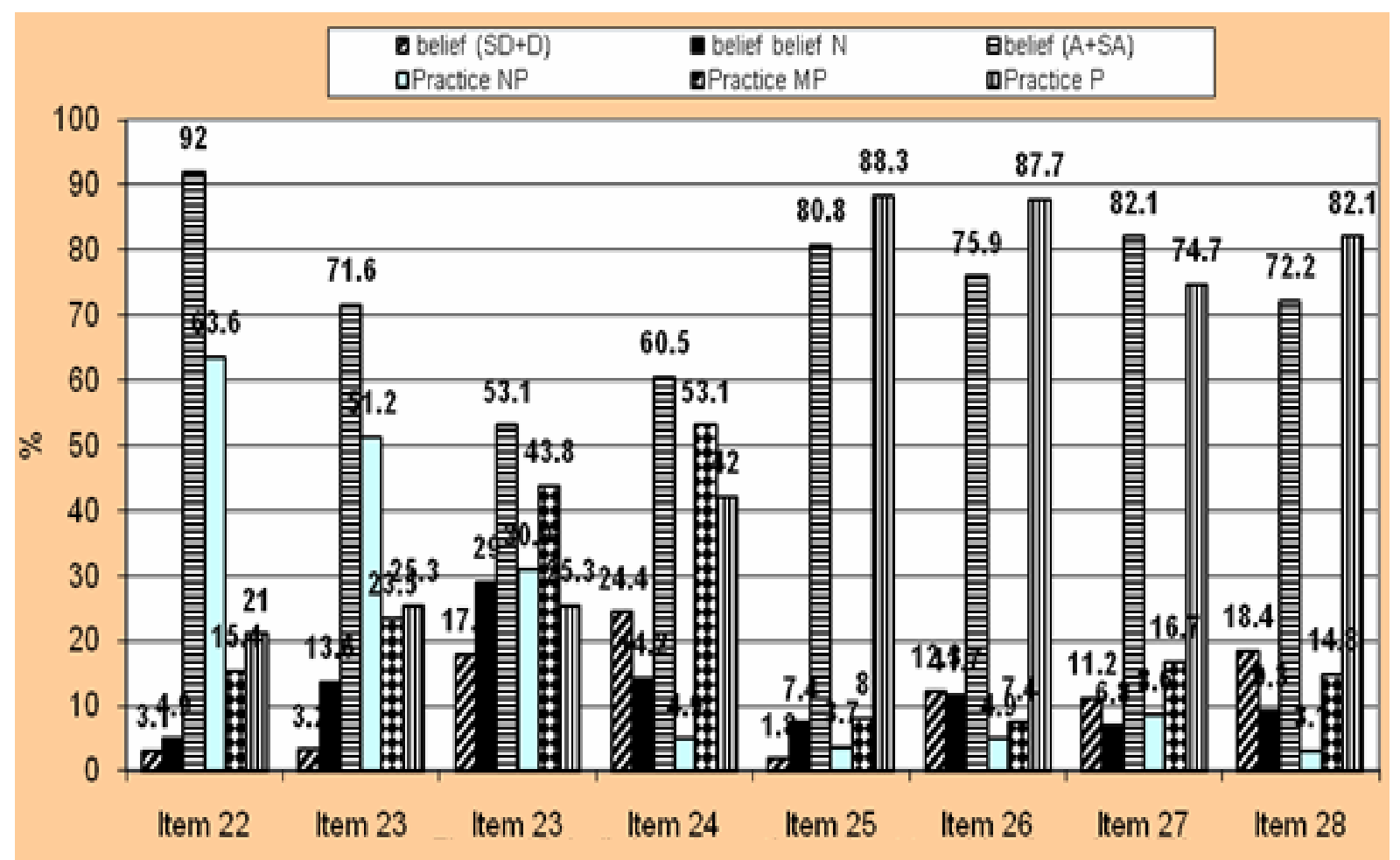

Figure 15. Beliefs and practices about Teaching/Learning STS

Note: $\mathrm{A}+\mathrm{SA}=$ agree belief responses, $\mathrm{N}=\mathrm{Neutral}, \mathrm{SD}+\mathrm{D}=$ disagree belief responses, $\mathrm{NP}=$ no practice, $\mathrm{MP}=$ Medium practice, $\mathrm{P}=$ practice Items are as follows:

- Constructivist views

22- Different sorts of activities should be used on teaching STS issue.

23- Students should relate the STS issue to their personal experience.

24- Societal dimension is the most important aspect of STS education

25- Science, technological, and societal dimensions should take equal attention in teaching science.

- Traditional views

26- Student should learn STS issues as on their textbook

27- It's more practical to give the whole class the same activity, one that can be done in short time.

28- Students need to memorize relevant facts within the STS issues and copy what teachers say.

As far as teachers' beliefs and practices about teaching/learning STS are concerned, on one hand, as the results been shown in Figure 15, one can easily notice that there was a great gap between teachers' constructivist beliefs and their constructivist practices. While a reasonable range of percentage (53.1-82\%) of teachers' responses indicated that the teachers hold constructivist beliefs, far fewer teachers (21-42\%) reported they are able to put these constructivist views in practices. On the other hand, there was consistency between teachers' traditional beliefs and their traditional practices. A vast percentage of the teachers (71.2$90.8 \%$ ) reported that they hold traditional beliefs about teaching/learning STS; for example they saw basic knowledge of science as a dominant aspect when using STS, and they also preferred teaching the STS issues as came in students' textbook. This indicated that teachers' traditional beliefs about teaching/learning STS were in alignment with their traditional practices.

To get an idea of the kind of the relationship between teachers' beliefs and practices and how much variance the two variables (beliefs- practices) share, the correlation coefficients and the coefficients of determination were calculated for each pair (belief-practice). As shown in Table 5 (see appendix A) the correlations between teachers' belief item scores and practice counterpart items were investigated using Pearson product-moment correlation coefficient. The results indicated that there was a medium positive correlation between each belief item and its practice counterpart. The correlation coefficients between the two variables (belief- 
practice items) ranged from 0.39 to 0.73 and all these correlation coefficients were significant at the 0.01 level (2-tailed).

This result can be interpreted that there is a kind of relationship between beliefs items and the practice ones. However, these correlation coefficients as shown in Table 5 say nothing about which variable causes the other to change. Although, we cannot make direct conclusions about causality, we can use the correlation coefficient a step further by squaring it to get the coefficient of the determination ( $\mathrm{r} 2$ ) which is a measure of the amount of variability in one variable that is explained by the other (Field, 2003). However, in our case, we can use (r2) to know how much variability exists in teachers' practices can be explained by teachers' beliefs.

As shown in Table 5, these two variables (belief-practice for each item) had a correlation ranged from 0.39 to 0.73 so the value of (r2) will be ranged from 1.52 to 5.33 . These results showed those teachers' beliefs help to explain nearly $15.2 \%-53.3 \%$ of the variance in respondents' scores on the practice items. This is quite a respectable amount of variance explained, when compared to a lot of the research conducted in the social sciences. To put this value of ( $\mathrm{r} 2)$ into perspectives, this leaves 46.7 to 84.8 of the variability of teachers' practices still to be accounted for by other variables. Although, teachers' belief variable can account for $15.2 \%-53.3 \%$ of the variation in practices scores, it does not necessarily cause this variation. However, to get deep understanding of the relationship between teachers' beliefs and their practices, there is a need for a qualitative analysis to discuss the reasons or constrains which acted as barriers of teachers to put their beliefs into practices.

\section{Inconsistency Between Beliefs And Practices}

To justify the inconsistency observed in teachers' responding to the items of beliefs and their responding to the items of practices, the open-ended question asked respondents to justify why they have difficulty practicing their educational beliefs regarding STS in the classroom. Answers to this question was qualitatively analysed and categorised into two main categorises, which are; external constraint and internal constraint.

External constrains included: Workload and general time constrains: (e.g. the teacher has to do other than teaching/learning duties, STS needs more than 45 minutes etc.). As Muskin (1990) and McCann and Johannessen (2004) cite these constrains represent the main reasons why teachers cannot practice their constructivist beliefs. These prevent teachers from taking the time to develop interactive lessons that demonstrate reflective thought from the students. Also with time constrain and the workload on teachers' shoulders, it is so difficult for the teachers to give the chance for students to think about their perception concerning relationship amongst science, technology, and society. However, in terms of time constrain, it is easy for the teacher to play the main role of explaining STS issues. This explains the matching of teachers' traditional beliefs with their traditional practice regarding "item of Explain the STS issue" and at the same time explains the mismatching teachers' constructivist beliefs with their constructivist practice regarding items ("Help students think about their ideas concerning the relationship between STS" and "Students should relate the STS issue to their personal experience"). Student expectation: (e.g. passing the exams, no attention to any information out of the textbooks).

Another external constrain mentioned by the respondents was large size of class: (e.g. students' number ranged from 50-65 students, no chance for communication or discussion STS issues, workload, a lot of written work). With an average of five classes of 50-65 students, teachers find it difficult to put forth the time and energy to put their constructivist 
beliefs their roles or teaching/learning STS into real practice in classroom when they could instead follow the simple lesson plans from the textbook and lecture in order to cover the content material required. In addition to the workload of teachers, monthly testes or end-ofyear tests act as a stressor that teachers face (e.g. emphasizing on achievement, assessing cognitive aims, standard for learning and knowing, evaluating both teachers and students, STS is not involved on textbook question or final exams). Science content: (e.g. more theoretical than practical, superficial in presenting STS issues, science content is predominant, the content covers the aims of cognitive domain more than STS one etc.).

As respondents mentioned, in order to complete all the material for the tests, teachers feel forced to spend very little time on activities that promote constructivist styled learning. That explains why there was consistency between teachers' beliefs and their practices on item "Decide not the students what STS activities are to be done" and item "It's more practical to give the whole class the same activity, one that short time", while why there was inconsistency between teachers' beliefs and their practices on item "Provide opportunities and resources for his students to discuss STS issue "and item "Different sorts of activities should be used on teaching STS issue". Also as respondents mentioned, lack of resources: (e.g. lack of books, instruments, computers, no slides, no photocopying) can cause these consistencies and inconsistencies. Classroom management and Student familiarity (e.g. students used to traditional teaching methods on different subject matters, controlling the students) was another reason why teachers find it difficult to implement their educational beliefs that focus on student-centred activities as in item 18 "Let the students themselves to ask questions about STS and to lead the discussion". In contrast, the teachers find it easy to implement their educational beliefs that focus on teacher-centred activities as in items related with traditional beliefs.

Other external constrains as respondents mentioned that act as stressors which in turn make the teachers focus on the science content as on the students' textbooks rather than STS include: Parents' expectation: (e.g. passing the exams with high scores), School policy: (e.g. headmaster's concern with position of school amongst the other schools in the whole school district, inspector's concern, sticking to teacher guide and student textbook, covering all the curricula in details and in certain time, sticking to the schedule of the syllabus distribution). Aims of science learning: (e.g. the main aims are the cognitive aims, which focus on memorising). Internal constrains included: Teachers' lack of knowledge: lack of knowledge related with STS issues 'subject matter knowledge' or the teaching methods of how to teach these issues 'subject specific pedagogical knowledge'. The reason for these internal constrains as respondents mentioned that there was lack of Training programmes: (e.g. No training related with STS, No training related with using computer or Internet)

\section{Discussion}

The findings of the study showed that the beliefs expressed by teachers concerning the relationship between science, technology and society were distributed across the naive, has merit, and realistic categorises. These findings concur with Rubba and Harkness' study (1993) in which, the responses of the pre-service and in-service science teachers to teachers beliefs about science, technology and society (TBA-STS) questionnaire were distributed also differentially across the naïve, has merit, and realistic categorises. The findings presented here, show that the science teachers may not hold adequate understandings of the nature of science and technology and their interactions. This result coincides with Celik and Bayrakçeken's (2006) conclusion that science teachers' conceptions about the nature of science could be considered relatively traditional prior to the STS course, This suggests that 
developing teachers' views about constructivist NOS may be an essential component of teacher training programmes.

The majority of the participants viewed that science is a body of knowledge to discover nature. According to this view, scientific knowledge is facts which are always truths. The roles of scientists in this case are only to record what exists and systematically organize the resulting body of knowledge. They do not use their imagination, originality, creativity or other individual attributes. They only pursue scientific method, which is a hierarchical sequence (questioning, hypothesizing, collecting data and concluding).

The present study concurs with Tairab (2001) that the views of a majority of the participating science teachers were divided between content-oriented and process-oriented science. Generally the views were spread from naive perspectives 'science as a study of fields such as biology, chemistry and physics' to more realistic views which regards science as a process-oriented human activity. Also, In Tairab's study (2001), science teachers participants' views regarding the nature of technology confirm the concern highlighted by Aikenhead and Ryan (1992) that the instrumentalist view often confuses science with technology with regard to the social purpose of both science and technology.

The majority of the teachers on the current study expressed technology as an application of science. This finding is consistent with many studies (e.g. Tairab, 2001; Yalvac, et al., 2007). This is a view characterised by Klein (1996) and Rubba and Harkness (1993) as naive. In this respect, Gardner (1999) noticed that the view of technology as an applied science is dominant among science educators and has strong cultural roots. Gardner argued that people tend to point to the artefacts that have followed scientific discoveries such as atomic physics and nuclear power generation, e.g. electrical research and dynamos, and consequently draw the conclusion 'Just learn science and one can become a technologist merely by applying scientific ideas' (p. 330).

The findings that expressed teachers' views of the relationship between science and technology and society are very complex and highlighted two different views; the constructivist and the traditional view. The basic beliefs of the constructivist view are the following: science is viewed as a set of socially negotiated understandings of the universe; knowledge is accepted if deemed viable by the scientific community; in addition to 'scientific method', there are other ways to gain scientific knowledge; scientists are influenced by prior knowledge, social factors and other influences; and scientific knowledge is intuitive and tentative. In this respect, Kranzberg (1991) mentioned that science and technology are very human activities and, as such, they are an inherent part of our social milieu. Also, the findings of the current study concur with Aikenhead (2004) the use of science and technology is based on our value system, as embodied in our religious and political ideologies and in our institutional structure. On the other hand the basic beliefs of the traditional view of science are the following: we can observe, know and predict the inner workings of the universe from an objective position; the only way to gain scientific knowledge is through the application of the induction method; scientists are absolutely objective not confined by the theories that they have; scientific knowledge is absolute and devoid of creativity and scientists' imaginations (Kuhn, 1970; Yildirim, 2000).

The findings indicate that the consistency on the teachers' responses about the relationship between science, technology and society was low. This means that the mental vision and the operational relationship between science and technology and their role in the society are not clear in the minds of the teachers, which may lead to ambiguity among their students (Zoller, et al., 1991; Rubba \& Harkness, 1993; Solomon, 2004; Aikeanhead, 2004). This shows that the teachers have not developed a clear idea about the role of science and 
technology in solving social problems, e.g., the problems of housing, health, farming, ways, reproduction, and energy. Some studies proved that science teacher preparation programmes do not highlight the nature of science, which should be an indispensable part of science education. Afifi (1992) found a general weakness among student teachers in regard to the understanding of the nature of science. He attributed this to (a) the absence of courses that tackle the nature, philosophy and history of science in the preparation programmes and (b) lecturers' negligence of the nature and identity of science when they teach. Lecturers are mainly concerned with reciting events.

The findings indicated that the Egyptian science teachers hold mixed beliefs (constructivist and traditional) concerning science education goals, their roles and their students' roles within teaching and learning science through STS and concerning teaching/learning science through STS. Teachers tended to respond to both the constructivist views and traditional views of the items of the questionnaire. These findings concur with other studies (e.g. Koballa et al., 2000; Flores, et al., 2000; Levitt, 2001, Tsai, 2002; Marton et al., 1993). In this respect, some studies in science education have reported that one person can display different or opposite beliefs (intra-personal diversity) about the same issue when surveyed through items that differ in format or context (Clough \& Driver, 1986; Taber, 2000). In attitudinal research, Vázquez Alonso, et al. (2005) refer that the presence of simultaneous opposite attitudes in the same person is a well-known fact that is commonly attributed to the latent role of attitudes, especially when they refer to topics not explicitly taught, as is the case in STS issues. Some scholars recognise that these opposite or inconsistent beliefs have been called indifferent, intermediate, incoherent, ambivalent or ambiguous answers. In spite of their scarcely defined appearance, they have frequently been attributed to the methodological weaknesses of the measurement instruments (Eagly \& Chaiken, 1993). Regardless of whether these statements on the questionnaire of STS teaching/learning philosophy carry over to teachers' actual teaching beliefs and practices, their endorsement of ideas about good STS teaching consistent with constructivist instruction and their equally choosing of traditional ideas about STS teaching/learning suggest one of two things: either teachers believe that it is necessary to make science education reform and that they should have those beliefs in forms of intentions (Mamlok-Naaman \& Hofstein, 2007) or these beliefs are actually ones that teachers hold (Bakar, Bal \& Akcay, 2006).

The findings of the study showed some evidence that teachers' beliefs of teaching STS, learning STS, and the nature of the relationship between STS are interconnected with each other. These results concur with Tsai (2002) who found that teachers' beliefs of teaching science, learning science and the nature of science are interrelated. However, although the study highlighted that there was interconnectedness among the different sets of teachers' beliefs, it does not necessarily mean that those teachers' beliefs of leaning and teaching STS necessarily influence the action of teaching science. In this respect, the findings of research showed that there are some consistency and some other inconsistency between teachers' beliefs and their practice.

There is possibility that social desirability plays some role in the distribution of survey responses and that includes the possibility that respondents perceived researcher opinion to favour constructivist statements which social desirability led them to endorse (Ravitz, Becker \& Wong; 2000; Smith, 2007). Having used a combination of questionnaires, interviews and group discussions to assess changes in educational attitudes, Shipman (1967) found several contradictions emerged. When Shipman examined the questionnaire responses, the data showed the usual progressive impact of the college on teacher perspectives. However students expressed opinions in their interviews that were more in line with traditional perspectives found in the schools. Further interviews with students to robe the reasons for the 
discrepancies led shipman to conclude that the progressivism with has been noted among university students does not represent the impact of college but merely a layer superimposed on a substratum of traditional perspectives which remain latent throughout professional training. He said "students maintained two levels of professional attitudes, one for official use on stage, and one for use backstage, out of official hearing, or later on in the classroom" (p. 55). Another explanation given by Gahin (2001) that the inconsistency of teachers' responses on the beliefs questionnaire which teachers tended to tick both positive statements and their negative counterparts that teachers' beliefs in and application of teaching and learning may not firmly established. He suggested deeper look into the reasons why teachers tended to be inconsistent in their responses and most of them hold mixed beliefs. Therefore, there is necessity to follow the interpretive paradigm to look deeply into the factors the affecting or forming teachers' beliefs and practices to know why teachers do that.

The findings indicated that teachers perceived the principal sources of constraints as 'external constraints'. This raises the question of why Egyptian teachers feel this way. It is possible that they feel that most, if not all, of the decisions related to their career come from the outside in a 'top down' manner. They do not contribute to any decisions regarding curriculum development, teacher training, teacher preparation etc. So they do not feel that they have to take responsibility for any changes or innovations. Decision makers should consider teachers' views when they implement changes related to the educational system. Changing the status quo in the science curriculum cannot be achieved by STS-like curriculum improvements based on coherent philosophical grounds alone. Real change requires political interventions based on creative and power-brokering politics (Aikenhead, 2002).

The present study revealed a number of factors that caused inconsistency between teachers' beliefs and their practices. Teachers considered constraints to act as boundaries that controlled their practices and limited their intentions and attempts to enact their beliefs in practices (Ajzen, 1988, 2002; Simonneaux, \& Albe, 2002, Author, 2007). As a result there was matching between traditional beliefs and traditional practices. The study's findings also concur with Tsai (2002) who studied a science teacher's views of STS instruction. Tsai (2002) identified factors that might impede the success of STS instruction, including the syllabus outlined by the national curriculum, standard tests, lack of administrative or peers' support, and resource limitations in local contexts. Tsai also suggested that many aspects of existing political realties, situations, and cultures affect the implementation of STS.

\section{Implications}

The findings presented here, show that the science teachers may not hold adequate understandings of the nature of science and technology and their interactions. Therefore, this may be a factor in the degree to which science teachers integrate STS into science instruction, the methods used to integrate STS into science instruction, and the quality of the STS instruction. So, as Bakar, Bal \& Akcay (2006) and Kaya et al., (2009) suggested, STS courses that focus particularly on the nature of science and technology and their interactions within society, might appear to be an appropriate way to help science teachers develop these understandings (Celik \& Bayrakçeken, 2006). Also, the findings of this study do agree with Zoller et al.' study (1991) that a special effort in the "STS literacy" domain should be made within both teacher training programmes and student STS teaching, concerning the science/technology/society interaction. In the same respect, El-Nemr and Tolymat (2000) suggest that a biology teacher education programme that focuses particularly on the nature of biology, science, and technology and their interactions within society and environment is an appropriate way to help science teachers develop their understanding of the relationship between science, technology and society. 
The findings have shown that teachers reflected both active and passive theories (traditional-constructivist theories) of learning and teaching science through STS. The comparison between each of the teachers' beliefs and practices has also revealed that generally the teachers' observed were more traditional than their expressed beliefs. This may result from two reasons: Firstly, it was possible that the teachers believe that it is necessary to make science education reform and that they should have those beliefs in forms of intentions (Fishbein \& Ajzen; 1975) or these beliefs are actually ones that teachers hold consciously or unconsciously. This implies that the role of science education not just to suggest new theories or teaching techniques, but that teacher educators need to allow teachers to explore and express their existing beliefs and try to assimilate new ideas by reforming their beliefs or constructing new beliefs.

The study provided an insight for science teacher education in Egypt both at pre-service and at in-service levels. It will be useful for science teacher educators since it aims to provide insights into the effect of science teachers' beliefs on classroom practice. According to Bybee (1997), one reason why previous science education reform efforts have failed is because "a consistent and coherent set of purposes, policies, programmes, and practices do not exist" (Bybee, 1997: 30). Setting policies or curriculum frameworks at the state, county or even for school level can influence practice in the classroom, but may not ensure that science teachers will appropriately or consistently translates the policies into practice. Bybee calls this "the policy-practice gap".

While it might appear beneficial to study entire systems of beliefs, such a focus may provide ambiguous results. As Klein (1996) observed, teachers' beliefs can be eclectic which means that teachers may hold contradictory sets of beliefs. For example, they may hold beliefs which reflect, at the same time, a constructivist and a transmissionist philosophy. This should not be surprising since teachers' beliefs or implicit theories are unlike official theories in that they are not organized into a coherent body of knowledge or an interrelated set of propositions or principles. Identifying particular, individual beliefs may assist in better understanding belief systems in general and the contradictions often inherent in them. Understanding individual's beliefs can help identify those beliefs, which may be more central to a particular learning theory. On a practical level, an understanding of individual's beliefs can assist in the design of professional development sessions.

For effective development of pedagogy and hence effective teaching techniques, teachers need to develop a sound and critical understanding of the nature of science and technology. This is particularly important because what science teachers choose to teach and how they teach it will be influenced by their views about the nature of science. The better to communicate scientific and technological ideas to students they must understand what they are attempting to communicate to their students (Lederman, 1992; Dillon \& Manning, 2010).

The study in its attempt to explore science teachers' beliefs about STS issues gave an insight to the curriculum developers about the important effect of teachers' beliefs on the development of the science curriculum. As McLaughlin (1987) has pointed out, "what actually is delivered or provided under the aegis of a policy depends finally on the individual at the end of the line..." (p.174). Aikenhead (2006: 62) argues that teachers construct their own meaning of any intended curriculum as they negotiate an orientation toward it and decide what to implement. Central to the realization of any curriculum implementation goal is the need for information concerning the beliefs that teachers hold about curriculum implementation and the origins of these beliefs. As Munby (1984) has clearly and articulately argued that" teachers' beliefs and principles are contextually significant to the implementation of innovations" (p.28). Research supports the idea that teachers are crucial change agents to 
educational reform and that teachers' beliefs are precursors to change (Ajzen, 1985; Pajares, 1992, Tsai, 2002; Mamlok-Naaman \& Hofstein, 2007).

This paper arise a lot of questions need to be investigated. Firstly, teachers tended to respond to both the constructivist views and traditional views of the items of the questionnaire. This needs more investigation to recover why teachers tended to be inconsistent in their responses and most of them seem to hold mixed beliefs. Secondly, the findings of the questionnaire shed light on some factors that face the teachers and act as barriers to put their beliefs into practices, but we still need to understand how these factors operate to stop teachers to implement their educational beliefs in STS classroom. So, we can skip over these constraints or change them. Also, the findings of the questionnaire arise question regarding whether belief and practice are consistent or inconsistent in teaching science through STS. Finally, the findings arise question about the direction of the relationship between belief and practice; whether belief affects practice or practice can change belief. To get deep understanding of all these issues arisen from the questionnaire findings, it is necessary to follow the interpretive paradigm in studying teachers' beliefs and practices.

\section{References}

Afifi, Y. (1998). Enquiry skills in science textbooks for the preparatory stage. Journal of Science Education. 1 (1)163-182. (published by Egyptian Society for Science Education, Ain Shams University, Cairo) (In Arabic).

Aguirre, J., Haggerty, S., \& Linder, C. (1990). Student-teachers' conceptions of science, teaching, and learning: a case study in preservice teacher education. International Journal of Science Education, 12, 381-390.

Aikenhead, G. (1984). Teacher decision making: the case of Prairie high. Journal of Research in Science Teaching, 21, 167-186.

Aikenhead, G. (2000). STS in Canada: From policy to student evaluation. In D.D. Kumar \& D.E. Chubin (Eds.), Science, technology, and society: A sourcebook on research and practice (pp.49-89). New York: Kluwer Academic/Plenum Publishers.

Aikenhead, G. (2004). STS education: a rose by any other name. In R. Cross (Ed.), A vision for science Education: Responding to the work of Peter Fensham (pp.59-75). London, RouledgeFalmer.

Aikenhead, G. (2006). Science education for everyday life: Evidence-based practice. New York: Teachers College Press.

Aikenhead, G., \& Ryan, A. (1989). The development of a multiple choice instrument for monitoring views on science-technology-society topics. Saskatoon, Saskatchewan, Canda: University of Saskatchewan, College of Education.

Aikenhead, G., \& Ryan, G. (1992). The development of a new instrument: Views on ScienceTechnology-Society (VOSTS). Science Education, 76 (5), 477-491.

Ajzen, I. (1985). From intentions to actions: a theory of planned behaviour. In J. Kuhl \& Beckman, J. (Eds.), Action control: from cognition to behaviour (pp.11-39). New York: Springer-Verlag.

Ajzen, I. (1988). Attitudes, Personality, and Behaviour. London: Open University Press, Milton Keynes.

Ajzen, I. (2002). Perceived behavioural control, self-efficacy, locus of control, and the theory of planned behaviour, Journal of Applied social Psychology, 32, 1-20. 
Amer, E. (2003). The effectiveness of using invention techniques in developing written composition and creative thinking of Egyptian EFL students. Unpublished $\mathrm{PhD}$ thesis, University of Exeter, Exeter, UK.

ASE (1981). Education through Science. ASE: Hatfield.

Bakar, E., Bal, S., \& Akcay, H. (2006). Preservice science teachers beliefs about sciencetechnology and their implication in society. Eurasia Journal of Mathematics, Science and Technology Education, 2(3), 18-32.

Barnes, B. (1985). About science. Oxford: Basil Blackwell.

Bybee, R. (1984). Global problems and science education policy, In R. Bybee, J. Carlson \& A. McCormack (Eds.), Redesigning Science and Technology Education 1984 NSTA Yearbook (pp. 60-75). Washington, DC: National Science Teachers Association.

Bybee, R. W. (1997). Achieving scientific literacy: From purposes to practices. Portsmouth, NH: Heineman.

Bybee, R., \& Mau, T. (1986). Science and technology related global problems: in international survey of science educators. Journal of Research in Science Teaching, 23(7), (599-618).

Carroll, T. M. (1999). Developing partnerships: teacher beliefs and practices and the STS classroom. Proceedings of the 1999 Annual international conference of the association for the Education Teachers in Science (pp.331-338). Greenville, NC: Association for the Education of Teachers in Science. (ERIC Document Reproduction Service No. ED 431626)

Clough, E. E., \& Driver, R. (1986). A study of consistency in the use of students' conceptual frameworks across different task contexts. Science Education, 70 (4), 473-496).

Dillon, J., \& Manning, A. (2010). Science teachers, science teaching: Issues and challenges. In J. Osborone \& J. Dillon (Eds.), Good practice in science teaching: What research has to say (pp. 20-45), (2nd Edition). Berkshire: Open University Press.

Dimopoulos, K., \& Koulaidis, V. (2003). Science and technology education for citizenship: the potential role of the press. Science Education, 87, 241-256.

Duggan, S. \& Gott, R. (2002). What sort of science education do we really need? International Journal of Science Education, 24 (7), 661-679.

Eagly, A.H. \& Chaiken, S. (1993). The psychology of attitudes. Forth Worth TX: Harcourt Brace College Publishers.

Eijkelhof, H., \& Lijnse, P. (1988). The role of research and development to improve STS education: experiences. International Journal of Science Education, 10 (4), 464-474.

El-Nemr, M., \& Tolymat, H. (2000). New prospective role for Biology teachers relevant to the year 2000 and beyond. paper presented to Proceedings of International Symposium conference "BioEd 2000" the Challenge of the next Century, 15-18 May, in the MNHN Grande Galerie de l'Evolution.

Fang, Z. (1996). A review of research on teacher beliefs and practices. Educational Research, 38(1), 47-64.

Fensham, P. J. (1988). Approaches to teaching of STS in science education. International Journal of Science Education, 10 (4), 346-356. 
Fishbein, M., Ajzen, I. (1975) Belief, attitude, intention and behavior: an introduction to theory and research. Reading, Massachusetts: Addison-Wesley, London.

Foster, P. (1996). Observational Research, in R. Sapsford and V. Jupp, eds., Data Collection and Analysis (pp.57-93). Newbury Park CA., SAGE.

Gahin, G. H. (2001). An investigation into EFL teachers' beliefs and practices in Egypt An explanatory study, Ph.D Thesis, school of Education, University of Exeter. Exeter, UK.

Gliem, J., \& Gliem, R. (2003). Calculating, Interpreting, and Reporting Cronbach's Alpha Reliability Coefficient for Likert-Type Scales. Paper presented at In 2003 Midwest Research to Practice Conference in Adult, Continuing and Community Education. Columbus, $\mathrm{OH}$.

Hart, E. P., \& Robottom, I. M. (1990). The Science-technology-society movement in science education: A critique of the reform process. Journal of Research in Science Teaching, $27(6), 575-588$.

Hurd, P. D. (1998). Scientific literacy: new minds for changing world. Science Education, 82, 407-416.

Jegede, O. J. (1988). The development of the science, technology and society curricula in Nigeria. International Journal of Science Education, 10(4), 399-408.

Jenkins, E. W. (1999). School science, citizenship and the public understanding of science. International Journal of Science Education, 21 (7), 703-710.

Kaya, O., Yager, R., \& Dogan, A. (2009) Changes in attitudes towards Science-TechnologySociety of Pre-service Science Teachers. Research in Science Education, 39(2), 257279.

Klein, P. (1996). Preservice teachers' beliefs about learning and knowledge. The Alberta Journal of Educational Research. Vol XLII, 4, 361-377.

Koballa, T., et al. (2000) Prospective gymnasium teachers' conceptions of chemistry learning and teaching, International Journal of Science Education, 22(2), 209-224.

Kolstoe, S. D. (2001). Scientific literacy for citizenship: tools for dealing with the science dimension of controversial socioscientific issues. Science Education, 85, 291-310.

Kranzberg, M. (1991). Science-Technology-Society: It's as simple as XTZ!. Theory Into Practice, Vol. XXX, No. 4, 234-241.

Kuhn, T. (1970). The structure of scientific revolutions (2nd edn). Chicago, IL, The University of Chicago Press.

Levitt, K. E. (2001). An analysis of Elementary teachers' beliefs regarding the teaching and learning of science, Science Education, 86, 1-22.

Longbottom, J., \& Butler, P. (1999). Why teach science? Setting rational goals for science education, Science Education, 83, 473-492.

Mamlok-Naaman, R., \& Hofstein, A. (2007). Involving Science Teachers in the Development and Implementation of Assessment Tools for "Science for All" Type Curricula, Journal of Science Teacher Education, 18(4), 497-524.

Mansour, N. (2007). Challenges to STS: Implications for science teacher education. Bulletin of Science, Technology and Society, 27(6), 482-497. 
Mansour, N. (2008). The experiences and Personal Religious Beliefs of Egyptian science teachers as a framework for understanding the shaping and reshaping of their beliefs and practices about Science-Technology-Society (STS). International Journal of Science Education, 30 (12), 1605-1634.

Mansour, N. (2009). Science teachers' beliefs and practices: issues, implications and research agenda. International Journal of Environmental and Science Education, 4(1), 25-48.

Mansour, N. (2009). Science-Technology- Society (STS): A new paradigm in Science Education. Bulletin of Science, Technology and Society,27(6), 482-497.

Mansour, N. (2010). The impact of the knowledge and beliefs of Egyptian science teachers in integrating an STS based curriculum. Journal of Science Teacher Education, 21(4), 513-534.

Marton, F., Beaty, E. and Dall'Alba, G. (1993). Conceptions of learning. International Journal of Educational Research, 19, 277-300.

McCann, T., \& Johannessen, L. (2004). Why do new teachers cry? The clearing House, 77(4), 134-145.

Munby, H. A. (1984). A qualitative approach to the study of a teacher's beliefs. Journal of Research in Science Teaching, 21, 27-38.

Muskin, C. (1990). Constraint of teaching methods and opportunity to learn in high school history classes. Paper presented at the Annual Meeting of the American Educational Research Association, Boston, MA. (ERIC Document Reproduction Service No. ED322038).

Noss, R., \& Hoyles, C. (1996). Windows on mathematical meaning. Dordrecht: Kluwer Academic Publishers.

Osborone, J. (2010). Science for citizenship. In J. Osborone \& J. Dillon (Eds.), Good practice in science teaching: What research has to say (pp46-67), ( $2^{\text {nd }}$ Edition). Berkshire: Open University Press.

Ost, D. H., \& Yager, R. E. (1993). Biology, STS \& the next steps in program design \& curriculum development. American Biology Teacher, 55(5), 282-287.

Pajares, M. F. (1992). Teachers' beliefs and education research: Cleaning up a messy construct. Review of Education Research, 62, 307-332.

Pedretti, E., \& Hodson, D. (1995). From rhetoric to action: Implementing STS education through action research. Journal of Research in Science Teaching, 32, 463-485.

Poulson, L., Avramidis, E., Fox, R., Medwell, J., \& Wary, D. (2001). The theoretical orientation of primary school literacy teachers: an exploratory study of orientations to reading and writing, Research Papers in Education, 16(3), 271-292.

Quicke, J. (2001). The science curriculum and education for democracy in the risk society. Journal of curriculum Studies, 33 (1), 113-127.

Ramsey, J. (1993). The science education reform movement: implications for social responsibility. Science Education, 77, 235-258.

Ramsey, J., \& Hungerford, H. (1989). The effects of issue investigation and action training on eighth-grade students' environmental behavior. The Journal of Environmental Education, 24 (3), 31-36. 
Ratcliffe, M., \& Grace, M. (2003). Science education for citizenship: Teaching socioscientific issues. Berkshire: Open University Press.

Ravitz, J., Becker, J., \& Wong, Y. (2000). Constructivist-compatible beliefs and practices among U.S. teachers. Retervied November 12, 2004, Available at http:// www.crito.uci.edu/tlc/html/findings.html.

Rubba, P. A. (1991). Integrating STS into school science and teacher education: Beyond awareness. Theory into Practice, 30, 303-308.

Rubba, P., \& Harkness, W. (1993). Examination of pre-service and in-service science teachers' beliefs about science-technology-society interactions, Science Education 77 (4), 407-31.

Ryder, J. (2002). School science education for citizenship: strategies for teaching about the epistemology of science, Journal of Curriculum Studies, 34(6), 637- 658.

Shipman, M. (1967) Theory and practice in the education of teachers. Educational Research, 9, 208-212.

Simonneaux, L. \& Albe, V. (2002). Teaching socially controversial scientific: resistances and motivations, real or perceived? in J. Lewis, A. Magro, L. Simonneaux (eds.), Biology Education For The Real World -Student - Teacher - Citizen. Toulouse: ERIDOB ENFA, pp. 121-134.

Smith, W. (2007) Social desirability bias and exit survey responses: The case of a first nations campground in Central Ontario, Canada. Tourism Management, 28 (3). 917-919

Solomon, J. (2004). The UK and the movement for science, technology, and society (STS) education. In R. Cross (Ed.), A vision for science Education: Responding to the work of Peter Fensham (pp.76-90). London, RouledgeFalmer.

Celik, S., \& Bayrakçeken, S. (2006). The effect of a 'Science, Technology and Society' course on prospective teachers' conceptions of the nature of science, Research in Science and Technological Education, 24(2), 255-273.

Taber, K. S. (2000) Multiple frameworks? Evidence of manifold conceptions in individual cognitive structure. International Journal of Science Education, 22, 399-417.

Tairab, H., H. (2001) Pre-service teachers' views of the nature of science and technology before and after a science teaching methods course. Research in Education, 65, 81-87.

Thirumarayana, M. O. (1998). An explanatory study of the relationships among science, technology, and society (STS) issues as conceived by fifth grade students. Journal of Elementary Science Education, 10(1), 60-75.

Tsai, C. (2002). Nested epistemologies: science teachers' beliefs of teaching, learning and science. International Journal of Science Education, 24(8), 771-783.

Vázquez Alonso, A., Manassero, M. A. \& Acevedo, J. A. (2005). Quantitative analysis of complex multiple-choice items in science technology and society: Item scaling. Revista Electrónica de Investigación Educativa, 7 (1). Retrieved April 14, 2010, year from: http://redie.uabc.mx/vol7no1/contents-vazquez.html

Waks, L. J. (1987). A technology credo. Bulletin of Science, Technology \& Society, 7(1-2), 357-366. 
Wiesenmayer, R., \& Rubba, P. (1999). The effects of STS issue investigation and action instruction versus traditional life science instruction on seventh grade students' citizenship behaviors. Journal of Science Education and Technology, 8 (2), 137-144.

Yager, R. E. (1993). Science - Technology - Society as Reform. School Science and Mathematics, 93 (3), 145-151.

Yalvac, B., Tekkaya, C., \& Kahyaoglu, E. (2007). Turkish pre-service science teachers' views on science-technology-society issues. International Journal of Science Education, 29 (3), 331-348.

Yetişir, M., \& Kaptan, F. (2008). STS from a historical perspective and its reflection on the curricula in Turkey. International Journal of Environmental and Science Education, 3(1), 3-8.

Yildirim, C. (2000). Philosophy of science. Istanbul: Remzi Publication.

Za'Rour, G. I. (1987). Forces hindering the introduction of STS education in schools. In Jegede, O. J. (1988) The development of the science, technology and society curricula in Nigeria. International Journal of Science Education, 10 (4), 399-408.

Ziman, J. (1994). The rationale of STS education is in the approach. In J. Solomon \& G. Aikenhead (Eds). STS education: international perspectives on reform. (pp.21-31). London: Teachers College Press.

Zoller, U., Donn, S., Wild, R., \& Beckett, P. (1991). Teachers' beliefs and views on selected science-technology-society topics: A probe into STS literacy vs STS indoctrination. Science Education, 74, 541-561.

\section{Appendix A}

Table 5. Correlations between teachers' items scores on beliefs scales and their scores on practices counterpart

\begin{tabular}{|c|c|c|c|c|c|c|c|}
\hline & & $\mathrm{N}$ & Mean & $\begin{array}{l}\text { Std. } \\
\text { D. }\end{array}$ & $(\mathrm{r})^{* *}$ & Sig. & $\mathrm{R} 2 * *$ \\
\hline & \multicolumn{7}{|l|}{ Science and technology } \\
\hline \multirow[t]{2}{*}{1} & Technology is the application of science (belief) & 162 & 4.3 & 1.06 & $0.43 *$ & 0.000 & 18.5 \\
\hline & $\begin{array}{l}\text { Technology is the application of science } \\
\text { (practice) }\end{array}$ & 162 & 2 & 0.88 & & & \\
\hline \multirow[t]{2}{*}{2} & $\begin{array}{l}\text { Science as a body of knowledge does affect } \\
\text { technology (belief) }\end{array}$ & 162 & 4.5 & 0.78 & $0.59^{*}$ & 0.000 & 34.8 \\
\hline & $\begin{array}{l}\text { Science as a body of knowledge does affect } \\
\text { technology (practice) }\end{array}$ & 162 & 2.2 & 0.87 & & & \\
\hline \multirow[t]{2}{*}{3} & $\begin{array}{l}\text { Technology does affect science to discover new } \\
\text { things (belief) }\end{array}$ & 162 & 4 & 1.22 & $0.59 *$ & 0.000 & 34.8 \\
\hline & $\begin{array}{l}\text { Technology does affect science to discover new } \\
\text { things (practice) }\end{array}$ & 162 & 2.2 & 0.87 & & & \\
\hline \multirow[t]{2}{*}{4} & $\begin{array}{l}\text { Technology provides tools and techniques for } \\
\text { science (belief) }\end{array}$ & 162 & 4 & 1.22 & $0.49^{*}$ & 0.000 & 24.0 \\
\hline & $\begin{array}{l}\text { Technology provides tools and techniques for } \\
\text { science (practice) }\end{array}$ & 162 & 2.2 & 0.87 & & & \\
\hline
\end{tabular}




\begin{tabular}{|c|c|c|c|c|c|c|c|}
\hline & & $\mathrm{N}$ & Mean & $\begin{array}{l}\text { Std. } \\
\text { D. }\end{array}$ & $(\mathrm{r})^{* *}$ & Sig. & $\mathrm{R} 2 * *$ \\
\hline \multirow[t]{2}{*}{5} & $\begin{array}{l}\text { Science does affect society to a great extent } \\
\text { (belief) }\end{array}$ & 162 & 4.2 & 1.12 & $0.64 *$ & 0.000 & 41.0 \\
\hline & $\begin{array}{l}\text { Science does affect society to a great extent } \\
\text { (practice) }\end{array}$ & 162 & 2.1 & 0.69 & & & \\
\hline \multirow[t]{2}{*}{6} & $\begin{array}{l}\begin{array}{l}\text { Science stimulates society to seek further } \\
\text { knowledge (belief) }\end{array} \\
\end{array}$ & 162 & 4.2 & 1.13 & $0.43 *$ & 0.000 & 18.5 \\
\hline & $\begin{array}{l}\begin{array}{l}\text { Science stimulates society to seek further } \\
\text { knowledge (practice) }\end{array} \\
\end{array}$ & 162 & 2.1 & 0.74 & & & \\
\hline \multirow[t]{2}{*}{7} & $\begin{array}{l}\text { Society does affect science to a great extent } \\
\text { (belief) }\end{array}$ & 162 & 3.6 & 1.16 & $0.73 *$ & 0.000 & 53.3 \\
\hline & $\begin{array}{l}\text { Society does affect science to a great extent } \\
\text { (practice) }\end{array}$ & 162 & 1.9 & 0.85 & & & \\
\hline \multirow[t]{3}{*}{8} & $\begin{array}{l}\text { Society's quest to understand the world } \\
\text { stimulates the accumulation of scientific } \\
\text { knowledge (belief) }\end{array}$ & 162 & 4.4 & 0.84 & $0.68 *$ & 0.000 & 46.3 \\
\hline & $\begin{array}{l}\text { Society's quest to understand the world } \\
\text { stimulates the accumulation of scientific } \\
\text { knowledge (practice) }\end{array}$ & 162 & 2.3 & 0.83 & & & \\
\hline & Technology and society & & & & & & \\
\hline \multirow[t]{2}{*}{9} & Technology makes life easier (belief) & 162 & 4.0 & 1.00 & $0.70^{*}$ & 0.000 & 49.0 \\
\hline & Technology makes life easier (practice) & 162 & 2.4 & 0.83 & & & \\
\hline \multirow[t]{2}{*}{10} & Technology does affect society (belief) & 162 & 4.0 & 1.22 & $0.59 *$ & 0.000 & 34.8 \\
\hline & Technology does affect society (practice) & 162 & 2.2 & 0.87 & & & \\
\hline \multirow[t]{2}{*}{11} & $\begin{array}{l}\text { Technology affects society by } \\
\text { The way society uses it (belief) }\end{array}$ & 162 & 4.0 & 1.1 & $0.56^{*}$ & 0.000 & 31.4 \\
\hline & $\begin{array}{l}\text { Technology affects society by } \\
\text { The way society uses it (practice) }\end{array}$ & 162 & 2.1 & 0.87 & & & \\
\hline \multirow[t]{2}{*}{12} & $\begin{array}{l}\text { Society's needs create demands for } \\
\text { Technology (belief) }\end{array}$ & 162 & 4.1 & 1.0 & $0.72 *$ & 0.000 & 52.4 \\
\hline & $\begin{array}{l}\text { Society's needs create demands for } \\
\text { Technology (practice) }\end{array}$ & 162 & 2.1 & 0.85 & & & \\
\hline \multirow[t]{3}{*}{13} & $\begin{array}{l}\text { Society puts restrictions on the use of } \\
\text { technology to control it (belief) }\end{array}$ & 162 & 4.5 & 1.13 & $0.59 *$ & 0.000 & 34.8 \\
\hline & $\begin{array}{l}\text { Society puts restrictions on the use of } \\
\text { technology to control it (practice) }\end{array}$ & 162 & 2.2 & 0.74 & & & \\
\hline & Constructivist beliefs about science teacher role & & & & & & \\
\hline \multirow[t]{2}{*}{15} & $\begin{array}{l}\text { Provide opportunities and resources for his } \\
\text { students to discuss STS issue (belief) }\end{array}$ & 162 & 3.9 & 0.95 & $0.56^{*}$ & 0.000 & 31.4 \\
\hline & $\begin{array}{l}\text { Provide opportunities and resources for his } \\
\text { students to discuss STS issue (practice) }\end{array}$ & 162 & 1.9 & 0.94 & & & \\
\hline \multirow[t]{2}{*}{16} & $\begin{array}{l}\text { Help students think about their ideas concerning } \\
\text { the relationship between STS (belief) }\end{array}$ & 162 & 4.1 & 1.13 & $0.73 *$ & 0.000 & 53.3 \\
\hline & $\begin{array}{l}\text { Help students think about their ideas concerning } \\
\text { the relationship between STS (practice) }\end{array}$ & 162 & 2.0 & 0.74 & & & \\
\hline \multirow[t]{2}{*}{17} & $\begin{array}{l}\text { Explore students' prior knowledge regarding } \\
\text { STS issues (belief) }\end{array}$ & 162 & 3.4 & 1.03 & $0.49 *$ & 0.000 & 24.0 \\
\hline & $\begin{array}{l}\text { Explore students' prior knowledge regarding } \\
\text { STS issues (practice) }\end{array}$ & 162 & 1.6 & 0.83 & & & \\
\hline \multirow[t]{2}{*}{18} & $\begin{array}{l}\text { Let the students themselves to ask questions } \\
\text { about STS and to lead the discussion (belief) }\end{array}$ & 162 & 3.8 & 0.97 & $0.65^{*}$ & 0.000 & 42.3 \\
\hline & $\begin{array}{l}\text { Let the students themselves to ask questions } \\
\text { about STS and to lead the discussion (practice) }\end{array}$ & 162 & 2.1 & 0.87 & & & \\
\hline
\end{tabular}




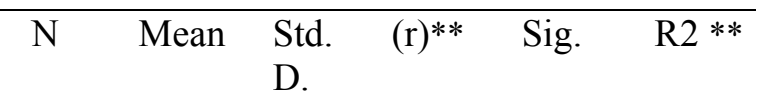

D.

Traditional beliefs about science teacher role

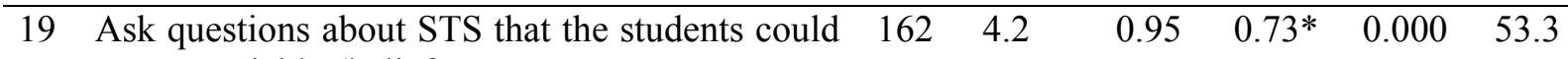
answer quickly (belief)

$\begin{array}{llll}\text { Ask questions about STS that the students could } & 162 & 2.8 & 0.51\end{array}$

answer quickly (practice)

\begin{tabular}{llllllll}
\hline 20 & Explain the STS issue (belief) & 162 & 4.4 & 0.74 & $0.61 *$ & 0.000 & 37.2
\end{tabular}

$\begin{array}{llll}\text { Explain the STS issue (practice) } & 162 & 2.7 & 0.69\end{array}$

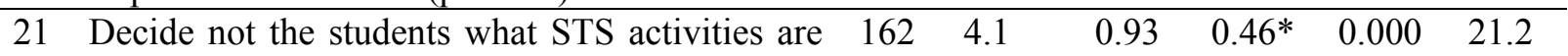
to be done (belief)

Decide not the students what STS activities are $162 \quad 2.8 \quad 0.58$

to be done (practice)

Constructivist beliefs about teaching/learning STS

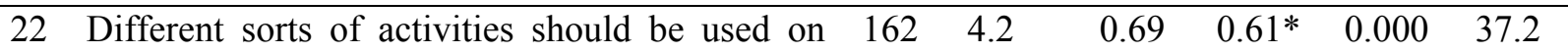
teaching STS issue (belief)

Different sorts of activities should be used on $162 \quad 1.6 \quad 0.81$

teaching STS issue (practice)

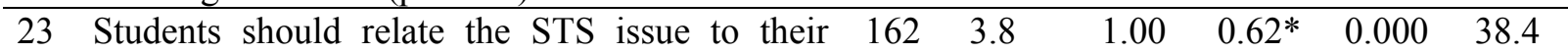
personal experience (belief)

$\begin{array}{lllll}\text { Students should relate the STS issue to their } & 162 & 1.7 & 0.84\end{array}$

personal experience (practice)

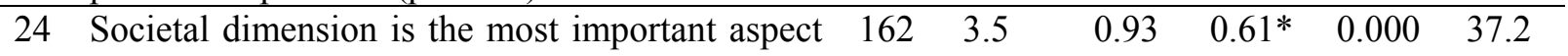
of STS education (belief)

Societal dimension is the most important aspect $162 \quad 2.0 \quad 0.75$ of STS education (practice)

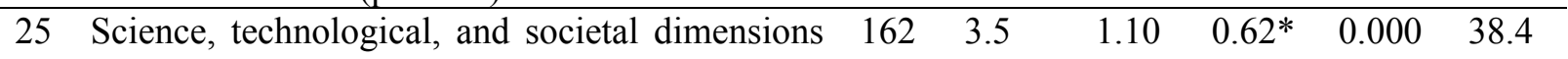
should take equal attention in teaching science (belief)

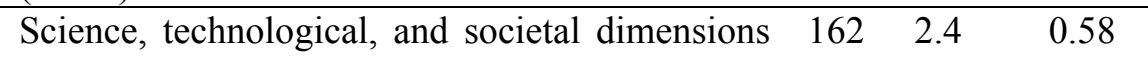

should take equal attention in teaching science

(practice)

Traditional beliefs about teaching/learning STS

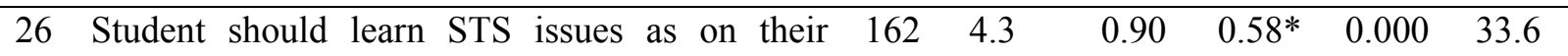
textbook (belief)

Student should learn STS issues as on their $162 \quad 2.8 \quad 0.47$

textbook (practice)

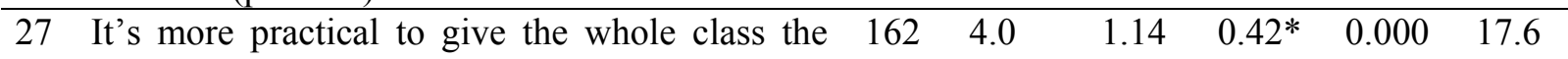
same activity, one that can be done in short time (belief)

It's more practical to give the whole class the $\begin{array}{llll}162 & 2.8 & 0.49\end{array}$ same activity, one that can be done in short time (practice)

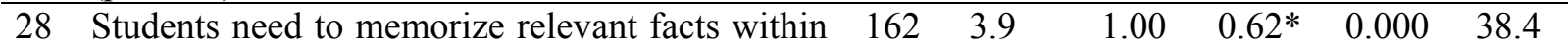
the STS issues and copy what teachers say (belief)

$\begin{array}{lllll}\text { Students need to memorize relevant facts within } & 162 & 2.7 & 0.63\end{array}$

the STS issues and copy what teachers say (belief)

\footnotetext{
* Correlation is significant at the 0.01 level (2-tailed).
}

$* * \mathrm{r}$ : correlation; $\mathrm{r}^{2}$ : coefficient of determination. 